\title{
HİZMET ROBOTU ENTEGRASYON İSTEKLİLIKK (HREİ) ÖLÇEĞİ: TÜRKÇEYE UYARLAMA, GEÇERLİK VE GÜVENİRLİK ÇALIŞMASI
}

\author{
Ayşegül ÖZKAN ${ }^{1}$ \\ Bülent AKKAYA2 \\ Hasan ÖZKAN ${ }^{3}$
}

Received Date (BaşvuruTarihi):

Accepted Date (Kabul Tarihi):

Published Date (YayınTarihi):
$11 / 08 / 2020$

$24 / 09 / 2020$

$25 / 09 / 2020$
$\ddot{O Z Z}$

\section{AnahtarKelimeler:}

Hizmet Robotu Entegrasyon İsteklilik Ölçeği,

Ölçek Uyarlama,

Robotik Sistemler,

Yapay Zekâ

JEL Kodlar:

M11,

M12,

L84

Keywords:

JEL Codes:
Service Robot Integration WillingnessScale
Hizmet robotu entegrasyonu istekliliği, yapay zekâ ve hizmet robotlarını düzenli hizmet işlemlerine entegre etme konusundaki uzun vadeli istekliliğini karakterize eden önemli bir faktördür. Bu araştırmanın amacı Lu, Chi ve Gursoy (2019) tarafindan geliştirilen Hizmet Robotu Entegrasyon İsteklilik Ölçeğinin Türkçeye uyarlanmasıdır. Ölçek orijinalinde 36 madde ve 6 faktörden oluşmaktadır. Farklı hizmet sektörlerinde faaliyet gösteren 673 çalışanın gönüllü katıldığı üç örneklem ile elde edilen veriler analiz edilmiştir. Ölçeğin yapı geçerliğini belirlemek için öncelikle keşfedici ve doğrulayıcı faktör analizleri yapılmıştır. Toplam varyansın \%73,01'ini açıklayan ve orijinaldeki gibi 6 faktörlü bir yapı elde edilmiştir. Fakat üç maddenin uyum iyiliği değerleri kabul edilen değer aralığında çıkmadığı için ölçekten sırasıyla teker teker çıkarılmıştır. Yapılan analizler sonucunda 33 maddeden oluşan ve orijinalindeki gibi 6 faktörlü bir ölçek yapısı elde edilmiştir. Elde edilen bulgular Hizmet Robotu Entegrasyonu İsteklilik Ölçeğinin Türkçe formunun farklı sektörlerde faaliyet gösteren kurum ve kuruluşlar için kullanılabilecek kabul edilebilir değerlerde güvenilir ve geçerli bir ölçme aracı olduğu söylenebilir.

$$
\text { M11 }
$$

\footnotetext{
${ }^{1}$ Doktora Öğrencisi, İstanbul Aydın Üniversitesi, aysegulalibasoglu@stu.aydin.edu.tr,

2 Dr. Öğr. Gör., Manisa Celal Bayar Üniversitesi, bulent.akkaya@cbu.edu.tr,

https://orcid.org/0000-0002-9625-0332

${ }^{3}$ Yüksek Lisans Öğrencisi, İstanbul Aydın Üniversitesi, hasanozkan@stu.aydin.edu.tr, 


\section{EXTENDED ABSTRACT}

\section{SERVICE ROBOT INTEGRATION WILLINGNESS (SRIW) SCALE:}

\section{ADAPTATION TO TURKISH, VALIDATION AND RELIABILITY STUDY}

\section{LITERATURE}

\subsection{RESEARCH SUBJECT}

Mechanization in human life has been continuing rapidly since the industrial revolution. With Industry 4.0, this process has accelerated, and machines have formed an essential part of human life. Accordingly, artificial intelligence has begun to be used at a high level,and the era of robotic systems, smart machines and robots has begun. In addition to the workforce, many tasks based on robotic processes have begun to be defined with more mechanization in all departments in businesses. These technologies are not only valid for mechanical works such as production and logistics, but are also used extensively in other departments such as personnel tracking, marketing and decision making. Therefore, interest in high-level artificial intelligence and robotics has increased, laboratory environments have been created, many types of research have been published, conferences, congresses and panels have started to be organized. For example, in a study conducted by Frey and Osborne (2015) on 702 professions in the USA; It has been stated that about half of the professions can be automated. The most significant source of this situation is, of course,the mighty foot steps of artificial intelligence. According to Eberl $(2019 ; 20)$, in this industry 4.0 period where there is a fundamental transformation in all living spaces of people; It is a matter of curiosity to what extent the investments for the future of artificial intelligence will affect people and what direction the willingness and readiness to have for this effect.

\subsection{RESEARCH PURPOSE AND IMPORTANCE}

The purpose of this study is to introduce the concept of Service Robot Integration Willingness developed by Lu, Chi and Gursoy (2019) and to adapt the Service Robot Integration Willingness (SRIW) scale to Turkish.

\subsection{CONTRIBUTION of the ARTICLE to the LITERATURE}

Although the scale is used by many researchers abroad, there has not been any study conducted in our country to adapt this scale to Turkish culture. In this study, the Service Robot Integration Willingness (SRIW) scale is adapted to the Turkish language and culture that contributes to the literature.

\section{DESIGN AND METHOD}

\subsection{RESEARCH TYPE}

The study is a quantitative method, and the data were collected by questionnaire.

\subsection{RESEARCH PROBLEMS}

Although the scale is used by many researchers abroad, there has not been any study conducted in our country to adapt this scale to Turkish culture

\subsection{DATA COLLECTION METHOD}

The Service Robot Integration Willingness scale originally consisted of 36 items and 6 factors. In this context, first of all, the meaning integrity of the Turkish translations of the scale, which includes 36 items, was reviewed. Service Robot Integration Willingness scale was adapted according to the adaptation method suggested by Brislin (1980). This method is a model that includes five necessary steps: 
1. Translating the scale into the target language to be used,

2. Evaluation of the translation made to the target language,

3. Re-translation into the source language,

4. Evaluating the repeat translation to the source language,

5. Final evaluation by experts.

\subsection{QUANTITATIVE/QUALITATIVE ANALYSIS}

Exploratory factor analysis (EFA) and confirmatory factor analysis (CFA) were performed.

\section{FINDINGS AND DISCUSSION}

Findings show that the factors in this study are interrelated and that there is only one factor that includes all factors. In this study, the model with acceptable goodness of fit values "second-order multifactorial model" is presented in Figure $1\left(\Delta \chi^{2}=750.059, \mathrm{sd}=489 \chi^{2} / \mathrm{sd}=1.53, \mathrm{NFI}=0.91, \mathrm{CFI}=\right.$ 0.94 GFI. $=0.92$, AGFI $=0.90$, RMR $=0.03$ RMSEA $=0.04$, and $p=.000$ ).

\subsection{DISCUSSING the FINDINGS with the LITERATURE}

In order to be able to plan and understand the futures of businesses in every aspect, it is thought that the Service Robot Integration Willingness Scale will benefit both academically and on a sectoral basis. The scale originally consists of 36 items and 6 factors. Data obtained from three samples voluntarily participated by 673 employees operating in different service sectors were analyzed. A 6factor structure that explains $73.01 \%$ of the total variance and as in the original was obtained.

\section{CONCLUSION, RECOMMENDATION AND LIMITATIONS}

The findings show that the Turkish form of the Service Robot Integration Willingness Scale is a reliable and valid measurement tool with acceptable values that can be used for institutions and organizations operating in different sectors. The final version of the scale is included in Annex-4.

The limitations of the study can be considered to reach a limited population in Marmara and Aegean Regions and the number of people evaluated is 673. Our suggestions include evaluating the employees in other regions, evaluating the differences between generations with a distinction, and determining the relationship and impact with different variables.

\subsection{RESULTS of the ARTICLE}

Service robot integration willingness is an important factor that characterizes the long-term willingness to integrate AI and service robots into regular service processes. The aim of this study is to adapt the Service Robot Integration Willingness Scale developed by Lu, Chi and Gursoy (2019) into Turkish. The scale originally consists of 36 items and 6 factors. The data was obtained from three samples and analyzed. In order to determine the construct validity of the scale, exploratory and confirmatory factor analyzes were performed first. A 6-factor structure that explains $73.01 \%$ of the total variance was obtained as in the original. However, since the goodness of fit values of the three items were not within the accepted value range, they were excluded from the scale one by one, respectively. As a result of the analysis, a scale structure consisting of 33 items and 6 factors as in the original was obtained. The obtained findings It can be said that the Turkish form of the Service Robot Integration Willingness Scale is a reliable and valid measurement tool with acceptable values that can be used for institutions and organizations operating in different sectors. 


\subsection{SUGGESTIONS BASED on RESULTS}

Our suggestions include evaluating the employees in other regions, evaluating the differences between generations with a distinction, and determining the relationship and impact with different variables.

\subsection{LIMITATIONS of the ARTICLE}

The limitations of the study can be considered to reach a limited population in Marmara and Aegean Regions, and the number of people evaluated is 673. 


\section{GİRIŞ}

Sanayi devriminden bu yana insan hayatında makineleşme hılı bir şekilde devam etmektedir. Endüstri 4.0 ile bu süreç daha da hızlanmış ve makineler insan hayatının önemli bir kısmını oluşturmuştur. Buna bağlı olarak yapay zekâ üst düzeyde kullanılmaya başlanmış ve robotik sistemlerin, akıllı (smart) makinelerin ve robotların dönemi başlamış bulunmaktadır. İşletmelerdeki tüm departmanlarda insan gücünün yanında daha fazla makineleşme ile birlikte robotik süreçlerin esas alındığı birçok görev tanımlanmaya başlamıştır. Bu teknolojiler sadece üretim ve lojistik gibi mekanik işler için geçerli olmayıp, personel takibi, pazarlama, karar alma gibi diğer departmanlarda da yoğun bir şeklide kullanılmaya başlanmıştır. Dolayısıyla üst düzeyde yapay zekâ ve robotiğe olan ilgi artmış, laboratuvar ortamları yaratılmış ve bunlara yönelik birçok araştırma yayınlanmış, konferanslar, kongreler ve paneller düzenlenmeye başlamıştır. Örneğin Frey ve Osborne (2015) tarafından $\mathrm{ABD}^{\prime}$ de 702 mesleğe yönelik yapılan bir araştırmada; mesleklerin yaklaşık yarısının otomatikleştirilebilir meslek olduğu ifade edilmiştir. Bu durumun en büyük kaynağ1 elbette yapay zekânın çok güçlü duyulan ayak sesleridir. Eberl(2019;20)'e göre insanlara ait tüm yaşam alanlarında temelden bir dönüşümün söz konusunun olduğu bu endüstri 4.0 döneminde; yapay zekânın geleceğine yönelik yatırımların insanları ne derecede etkileyeceği, bu etkiye olan isteklilik ve hazır olma durumunun ne yönde olduğu merak konusudur.

İnsan düzeyinde hizmet gösterebilen bir makine yaratma arzusu taşıyan tüm araştırmacıların, konuya yaklaşım biçimleri hep aynı sorunsal ile olmuştur; "Makineler düşünebilir mi?" (Turing, 2009). Bu soruya yönelik henüz net bir cevap bulunamadığı gibi, makinelerin akıllı olsun ya da olmasın günlük yaşamda ve çalışma alanlarında insanoğluna sağlayacağı fayda ve zararlara ilişkin yorumlar ve sonuçlar büyük önem arz etmektedir. Bu bağlamda çalışmanın amacı, son dönemde birçok alanda tartışılmakta olan; Lu, Chi ve Gursoy (2019) tarafından geliştirilen Hizmet Robotu Entegrasyon İstekliliği (Service Robot Integration Willingness) kavramını tanıtmak ve Hizmet Robotu Entegrasyon İstekliliği (HREİ)ölçeğini Türkçeye uyarlamaktır. Ayrıca hizmet robotu entegrasyon istekliliğine yönelik fiziksel olarak gözlemlenebilen hizmet robotlarınındikkate alındığı bu çalışmada 
öncelikle teorik arka plandan bahsedilerek hizmet robotu entegrasyon istekliliğinin yönünü belirlemek, konu hakkında farkındalık sağlamak ve konuya ilişkin ölçeğin literatüre kazanımını sağlamak hedefler arasında yer almaktadır.

\section{TEORİK ÇERÇEVE}

Akıllı olarak ifade edilen milyonlarca makine günümüzde hayatı kolaylaştırmak adına birçok alanda farklı amaçlar için kullanılmaktadır. Kaynak yapan makineler, montaj yapan robot kolları, evlerdeki akıllı süpürgeler, küçük ev aletleri, navigasyon cihazları, sesli yanıt sistemleri gibi cihazlar günümüzde çok rastlanılan basit robotlardır. Örneğin Roomba, 2002 yılında ilk elektrikli robot süpürge olarak piyasaya sürülmüştür (Jones, 2006). 2011 yılında Apple Iphone markasıyla piyasaya sürdüğü akıllı telefonlarında Siri'yi kişisel asistan olarak tanıtmıştır (Lemon ve Pietquin, 2012). Akıllı makineler arasında gösterilebilecek nitelikte olan Mercedes S500 Intelligent Drive; 100 kilometrelik bir yolu sürücüsüz olarak gidebilen ilk araç olma özelliğini taşımaktadır ("Mercedes-Benz,2020“). Bunun yanı sıra Sentker (2015) çalışmasında tarımda kullanılan robot teknolojisi ile literatüre büyük katkı sağlamıştır. Çalışma robotların toprağı gübrelemesinden, tohum zararlılarının önlenmesine ve hasadın toplanmasına kadar olan süreçte, droneler vasıtasıyla da hasat kaybının önlenmesine yönelik proaktif kararların alınması amacına hizmet etmektedir. California'da çeşitli otellerde kullanılan ve otel müşterilerine diş fırçası, gazete, havlu ve diğer gereksinimleri ulaştırma amacıyla kullanılan robotlar ise, personel yükünü azaltma yolunda işletmelere yardımcı olduğu ifade edilmektedir (“TheRoom Service Robots,2015”). Yaşlilara hizmet etmesi için tasarlanan robot Kuka ise ayağa kalkmalarında yardım amaçlı ve ilaçlarını almaları konusunda hatırlatıcı olarak onların hayatını kolaylaştırmaktadır ("Kuka, $\left.2020^{\prime \prime}\right)$.

Bu robotik sitemleri çok daha ileri götüren ve geliştiren bilim insanları kaslara, kirişlere ve eklemlere sahip insansı robotları da her geçen gün daha da gelişmiş haliyle insanlığa tanıtmaktadır. Asimo, Roboy, Icub, Sophia Dünya genelinde en çok tanınan insansı robotlar olup bu robotları geliştiren firmalar en ünlü robotik firmalardır ("Asimo,2020"; “Roboy,2020”; “Icub, 2020”; “Sophia, 2020”). Ülkemizde 
de Beyond Robotics ve Akın Robotics, robot alanında yatırım yapan şirketler arasındadır (“Beyond Robotics, 2020"; “Ak1n Robotics,2020”).

\subsection{Yapay Zekâ}

Günümüzde birçok alanda kullanılan ve tanımlaması yapılan yapay zekâ kavramı ilk kez 1956 yılında John McCarthy'nin planlanan bir konferansın başlığını "yapay zekâ" olarak önermesi ve önermesinin kabul edilmesiyle tanıtılmıştır (McCarthy, Minsky, Rochester ve Shannon, 2006). McCarthy (2007)'e göre yapay zekâ "Akıllı makineler, özellikle akıllı bilgisayar programlan yapma bilimi ve mühendisliği" olarak tanımlanmaktadır. İnsan zekâsını anlamak için bilgisayarların kullanılması gibi benzer bir görevle ilgilidir. Ancak yapay zekâ kendisini biyolojik olarak gözlemlenebilir yöntemlerle sınırlamak zorunda değildir. Bu sınırlamanın olmaması örneğin sanal asistanlar ve sohbet botlarının hizmet robotu olarak entegre edilmesinin önünü açan teknolojik gelişmeler sağlamıştır.

Yapay zekâ, operasyonel verimliliği artırmak ve müşteri deneyimini iyileştirmek için gün geçtikçe daha çok hizmet kuruluşlarına bir araç olarak nüfuz etmektedir (Prentice ve Nguyen, 2020). Yapay zekânın yetenekleri, sergileyebilecekleri insan becerilerine göre farklı kategorilerde önerilmektedir. Huang ve Rust (2018) hizmet işlerinde dört farklı beceri önermiştir. Bunlar; mekanik, analitik, sezgisel ve empatikzekâdır. Çünkü yapay zekâ sistemleri, mekanik görevlerden başlayıp empatik görevlere kadar bu becerileri gerektiren görevleri insanlardan daha iyi yapmayı başardığı için, hizmet otomasyonunun insan emeğinin yerini alabileceğini iddia etmişlerdir.

\subsection{Hizmet Robotları}

Robot terimi, zorunlu çalışma veya zorla çalıştırma anlamına gelen Çekçe "robota" kelimesinden gelmektedir ve ilk olarak Çek oyun yazarı KarelCapek tarafından "Rossum'un Evrensel Robotları" adlı kurgu oyununda tanıtılmış sonra dünya dillerinde kullanılmaya başlanmıştır (Klíma, 2001). Robotların fiziksel görünüşlerini tanımlamak için, insansı veya android gibi terimler kullanılmakta ve antropomorfik figürlere sahip robotlara atıfta bulunmak için genellikle ayrım 
gözetilmemektedir (VanDoorn, Mende, Noble, Hulland, Ostrom, Grewel ve Petersen, 2016).

Uluslararası Standardizasyon Örgütünün ISO 8373:2012 standardına göre hizmet robotları, "Endüstriyel otomasyon uygulamaları dışında insanlar veya ekipman için faydalı görevler gerçekleştiren bir robot" olarak tanımlanmaktadır ("International OrganizationforStandardization, 2012"). ISO 8373'e göre robotlar, "insan müdahalesi olmadan mevcut duruma ve algılamaya dayalı olarak amaçlanan görevleri yerine getirme yeteneği" ve "bir dereceye kadar özerklik" gerektirir. Hizmet robotları için bu, insan-robot etkileşimi dâhil olmak üzere kısmi özerklikten, aktif insan-robot müdahalesi olmadan tam özerkliğe kadar uzanmaktadır. Hizmet robotları ön saflardaki çalışanlar olarak hareket ettiğinde, insan benzeri hizmetler ve etkileşimler sunmaktan ve müşteri deneyimlerini gerçek zamanlı olarak iyileştirmekten sorumludurlar. Böylelikle yenilikçi hizmet modelleri sunularak, farklı sektörlerin sürdürülebilir rekabet gücü için iyi bir strateji oluşturulabilmektedir (Kuo, Li-Cheng ve Tseng, 2017).

\section{LITERATÜR TARAMASI}

Literatürde yapay zekâ, robotik sistemler ve hizmet robot servisleri hakkında birçoğu yeni olmak üzere farklı çalışmalar bulunmaktadır. SeverinsonEklundh,Green ve Hüttenrauch (2003), robotların hızlı bir şekilde insanların hayatlarının bir parçası olacak şekilde tasarlanmasıyla birlikte, insan sosyal ve iletişim becerilerinden faydalanarak, insanlar ve robotlar arasındaki etkileşimin yeni modellerini gerektirdiği düşüncesinden yola çıkarak bir araştırma gerçekleştirmişlerdir. Araştırmacılara göre, insan-robot ilişkileri robotların kullanımı bağlamında anlaşılmalı ve gerçek ortamlarda insanlar ve robotlar üzerinde yapılan deneysel çalışmalara dayanmalıdır. Çalışmalarının neticesinde elde ettikleri sonuçlardan biri, hizmet robotundaki sadece birincil kullanıcıya hitap etmenin tatmin edici olmadığ 1 ve odaklanmanın, robotun kullanılacağ1 insan grubunun ayarı, faaliyetleri ve sosyal etkileşimleri üzerinde olması gerektiğidir. Oistad,Sembroski, Gates, Krupp, Fraune veŠabanović (2016) ise robotların meslektaş mı yoksa araç mı olduğu ile ilgili soruya cevap aramak üzere yaptıkları bir araştırmada etkileşimin, bir 
artırdığını savunmuşlardır. Birlikte çalışma ilişkilerinde, insanlar sosyal olarak etkileşimli robotları antropomorfik hoşlanmaları için veya işlevsel robotları katı görev yönelimleri için takdir edebilmektedir. Yaptıkları çalışma, üst düzey amaca sahip bir görev sırasında insanlara karşı etkileşimli veya işlevsel olarak davranan robotların karşılaştırmalı olarak algılanan avantajlarını incelemektedir. Katılımcıların yanıtları doğrultusunda, görev sırasında robotlarla ilgili algıları ve algılanan iş birliği değerlendirilmiştir. Sonuçlar, katılımcıların fiziksel olarak daha yakın durduğunu ve etkileşimli robotları fonksiyonel robotlardan daha antropomorfik, sempatik ve saygın olarak değerlendirdiklerini; ancak iki robot türünü iş birliği açısından farklı değerlendirmediklerini göstermiştir. Katılımcılardan robotları daha çok insana benzetip, sempati ve sayg1 duyanlar, gelecekte robotlarla çalışma konusunda da bir o kadar fazla isteklilik dile getirmişlerdir.

Bunun yanı sıra birçok farklı alanda araştırmalar mevcuttur. Triebel, Arras, Alami, Beyer, Breuers, ChatilaveZhang (2016), yoğun havalimanlarında yolcu rehberliği ve yardım için sosyal açıdan duyarlı Spencer adlı bir hizmet robotu geliştirilmesi ile ilgili bir çalışma yapmışlardır. Avrupa Birliği tarafından finanse edilen Spencer projelerinde geliştirilen sosyal olarak uyumlu bir mobil robotik platformun geniş bir tanımını sunmuşlardır. Bu robotun amacı, büyük ve yoğun havalimanlarındaki yolculara yardımcı olmak, bilgi vermek ve rehberlik etmektir. Spencer'ın ana katkıları; insan sosyal davranışlarını algılamak, öğrenmek, modellemek ve bu bilgilerile mobil platformlar için gerçek zamanlı olarak uygun eylemleri planlamak ve kullanmak amacıyla yeni yöntemler geliştirmesidir. Araştırmada projenin bireylerin ve grupların saptanması ve izlenmesi, insan sosyal ilişkilerinin ve faaliyetlerinin tanınması, normatif insan davranışı öğrenme, sosyal olarak farkında görev ve hareket planlama, sosyal olarak açıklamalı haritaların öğrenilmesi ve normatif robot davranışlarının sosyo-psikolojik etkilerini değerlendirmek amacıyla ampirik deneylerin yapılması alanlarını nasıl ilerlettiğini açıklamaktadır.

Öte yandan Pinillos, Marcos, Feliz, Zalama ve Gómez-García-Bermejo(2016), otel ortaminda Sacarino adlı bir hizmet robotunun uzun dönem değerlendirmesi ile ilgili bir çalışma gerçekleştirmişlerdir. Çalışmanın amacı; robotun bir otelde komi 
olarak yeteneklerini geliştirmek, misafirlerin yanında yürümek, şehir ve otel hakkında bilgi vermek ve otelle ilgili hizmetler sağlamaktır. Bu çalışmanın bir diğer amac1, gezinti ve konuklarla etkileşim konusunda bir dizi metriğin sürekli ölçümüne dayalı üç aşamalı bir değerlendirme metodolojisi oluşturmaktır. Sacarino, gerçek bir otel ortaminda uzun süre otomatik olarak bilgi toplamakta, edinilen bilgiler analiz etmek ve ardışık iyileştirmeler yoluyla robotun oteldeki çalışmasını iyileştirmek için kullanılmaktadır.Araştırmacılar sonuçları analiz ettiklerinde robotun, katma değerli hizmetler sağlaması gerektiği gibi birtakım ilginç hususlar ve faydalı ipuçları elde etmişlerdir. Robotlar kullanıcıların büyük ilgisini çekebilir ancak robot başka bir şey sunamazsa, kullanıcilar zamanla ilgilerini kaybetmektedir. Lin, Chi ve Gursoy (2020), müşterilerin konaklama hizmetlerinde yapay olarak akıllı robotik cihaz kullanımını kabul etmesinin öncülleri üzerine yaptıkları araştırmada misafirperverlik hizmetlerinde müşterilerin yapay zekâlı robotik cihazları kullanma istekliliğinin ve itirazının öncüllerini incelemektedir. "Yapay Zekâlı Cihaz Kullanım Kabulü (AIDUA)" teorisine dayanan bu çalışma, ağırlama hizmeti ortamında AIDUA çerçevesini doğrulamakta ve genişletmektedir. Sonuçlarda AIDUA çerçevesinin uygulanabilirliğine işaret ederek,müşterilerin yapay zekâlı cihazları kullanma niyetinin sosyal etki, hedonik motivasyon, antropomorfizm, performans ve çaba beklentisi ve yapay olarak akıllı cihazlara yönelik duygulardan etkilendiği öne sürülmektedir. Bulgular ayrıca, tam hizmet sunan otelin müşterilerinin yapay zekâ cihazlarının kullanımına hem istekli hem de itirazda bulunma olasılığının yüksek olduğunu ortaya koymuştur. Buna karşılık, sınırlı hizmet sunan otelin müşterilerinin, yapay zekâ robotik cihazları kullanarak daha doğru ve verimli hizmetler almak adına sosyal etkileşim ihtiyacından vazgeçebileceklerini ortaya koymuştur. Bu bulgular; tam hizmet sunan otelin müşterilerinin, bu yapay zekâ cihazlarının sunduğu performans ve hedonik faydalar nedeniyle yapay zekâ hizmet cihazlarını kullanmaktan zevk alırken yine de insan çalışanlarla etkileşimde bulunmak istediklerini göstermektedir. Bu nedenle tam hizmet veren otel yöneticileri, insan çalışanlarını değiştirmek yerine onları güçlendirmek için yapay zekâ cihazlarını kullanmayı düşünebilir. Sınırlı hizmet sunan bir otelde, yapay zekâ robotik cihaz istenen fayda ve yeniliği sunabiliyorsa müşterilerin robotik hizmetleri 
sosyal etkileşimler hakkında çok az endişe duyarak kabul etmesi muhtemeldir. Bu nedenle sınırlı hizmet sunan otellerin yöneticileri, işletme maliyetlerini düşürmek için insan çalışanlarını robotik hizmet cihazlarıyla değiştirmeyi düşünebilirler.

Firmaların kendilerini geliştirmeleri ve birçok zorluğun üstesinden gelmeleri için robotik sistemler önem arz etmektedir. You ve Robert Jr. (2018), kuruluşların artık çalışanlarını robotlarla birlikte çalışmaya teşvik etme konusunda yeni bir zorlukla karşı karşıya olduklarını ifade etmektedir. Çalışmalarında insan-robot benzerliğinin, bir robota olan güvenin ve fiziksel tehlike riskinin, bireylerin bir robotla çalışma istekliliği ve bir insan iş arkadaşı yerine bir robotla çalışma istekliliği üzerindeki etkilerini araştırarak bu sorun ele alınmaktadır. Elde ettikleri sonuçlar, insan-robot benzerliğinin bir robota olan güveni artırdığını, bunun da robotlarla çalışma isteğine ve nihayetinde bir insan meslektaş yerine bir robotla çalışma isteğine yol açtığını göstermiştir. Araştırmacılar insan-robot etkileşimi teorisi ve robot tasarımı için çeşitli çıkarımları tartışarak yazına katkı sağlamışlardır. Bunun yanı sıra firmaların belirli departmanları için de bu sistemler etkili rol oynamaktadır. Shi, Jason ve Mark (2020), Delphi tekniğini kullanarak gerçekleştirdikleri çalışma, insan kaynakları uzmanlarının hizmet robotlarını nasıl algıladıklarını, konaklama endüstrisindeki liderliği ve insan kaynakları yönetimini nasıl etkileyeceğini araştırmayı amaçlamaktadır. Sonuçlar, hizmet robotlarının otel faaliyetlerinin verimliliğini ve üretkenliğini artırması beklenirken, aynı zamanda yüksek maliyetler, beceri eksiklikleri ve otellerin organizasyon yapısı ve kültüründe önemli değişiklikler gibi zorluklar oluşturabileceğini göstermektedir. Bu nedenle, robotik teknolojinin beklenen uygulamaları ve entegrasyonu, geleceğin liderlerinin misafir deneyiminde hizmet robotları ve insan çalışanlarının rolleri arasındaki dengeyi dikkatlice düşünmelerini, açık fikirlilik ve değişimi kucaklayan bir çalışma ortamını beslemelerini gerektirecektir.

$\mathrm{Bu}$ robotik sistemler ve yapay zekâ sadece üretim alanında faaliyet gösteren firmaların yanı sıra hizmet üretimi yapan ve sunan işletmeler için de gün geçtikçe vazgeçilmez bir unsuru haline gelmektedir. Gursoy, Chi, Lu ve Nunkoo(2019), tüketicilerin hizmet sunumunda yapay zekâlı cihaz kullanımını kabul etmeleri ile ilgili bir çalışma yapmışlardır. $\mathrm{Bu}$ çalışmada, müşterilerin hizmet 
etkileşimlerindeyapay zekâ cihazı kullanımını kabul etme istekliliğini açıklamayı amaçlayan yapay olarak akıllı cihaz kullanımı kabulünün (AIDUA) teorik bir modelini geliştirmişlerdir. Önerilen model, üç kabul üretme aşamasını (birincil değerlendirme, ikincil değerlendirme ve sonuç aşaması) ve altı öncülü (sosyal etki, hedonik motivasyon, antropomorfizm, performans beklentisi, çaba beklentisi ve duygu) içermektedir. Potansiyel müşterilerden toplanan veriler kullanılarak önerilen AIDUA modeli test edilmiştir. Bulgular ise müşterilerin hizmet etkileşimleri sırasında yapay zekâcihazlarının kullanımını kabul edip etmeyeceklerine karar vermek için üç aşamalı bir kabul oluşturma sürecinden geçtiğini kanıtlamaktadır. Sonuç olarak, sosyal etki ve hedonik motivasyonun performans beklentisiyle pozitif yönde ilişkili olduğu, antropomorfizmin ise çaba beklentisiyle pozitif yönde ilişkili olduğu ortaya konmuştur.

Hizmet robotları ve yapay zekâ, üretkenliği artırmayı ve maliyetleri düşürmeyi vadederek bunların satışı ve sonuçlarını anlamaya yönelik araştırmalarda önemli bir artışa neden olduğunu vurgulayan Belanche,Casaló, Flavián ve Schepers (2020), hizmet robotu uygulaması üzerine yaptıkları araştırma ile teorik bir çerçeve çizmişlerdir. Robot tasarımı, müşteri özellikleri ve hizmetle karşılaşma özelliklerinden oluşan üç bölümlü çerçeve; farklı hizmet bileşenlerine en uygun adaptasyonlarını belirlemek için her bir kategoride birlikte analiz edilmesi gereken temel faktörleri belirtmektedir. Tanımlar ve kavramlar, her değişken hakkındaki önceki bilgiler ve çözülmesi gereken araştırma boşlukları ile birlikte açıklığa kavuşturulmuştur. Bu çerçeve ve araştırma soruları, akademisyenlere rehberlik etmek ve uygulayıcılara hizmet robotlarını başarıyla uygulamalarına yardımcı olmak için bir araştırma gündemi sağlamaktadır.

\section{HİZMET ROBOTU ENTEGRASYON İSTEKLİLİĞİ ALT BOYUTLARI}

Lu vd. (2019) tarafından,hizmet robotu entegrasyon istekliliği altı farklı boyut olarak kategorize edilmiştir.

Performans Etkililiği: Lu vd. (2019) mevcut bağlamda, gönüllü kullanımında davranışsal niyetlerin en güçlü öngörücüsü olarak tanımladıkları performans etkililiği, robotların tüketicilere tutarlı ve güvenilir hizmet sunma derecesini 
karakterize etmektedir. Bu boyut hizmet robotlarının ön hizmetlerini yürütürken görev performansında yetkin olup olmadıkları, algılanan hizmet kalitesi ve müşteri deneyimi ile ilgilidir.

İçsel Motivasyon: İçsel motivasyon; memnuniyet veya ödülün harici bir kaynaktan değil, faaliyetin kendisinden geldiği zevkli bir faaliyete girme eylemi olarak ifade edilmektedir. Psikoloji ve robotikte bu, davranışları yeni ve şaşırtıcı aktivitelere yönlendiren içsel bir motivasyon biçimi olan bilişsel merak fenomeni ile bağlantılıdır (Oudeyer, KaplanveHafyer, 2007). İçsel olarak motive edilmiş aracılar, çevrimiçi kendi kendine eğitim örnekleri oluşturarak verileri toplayarak ve aşamalı bir şekilde beceriler kazanmaktadır (Parisi, Kemker, Part, Kanan ve Wermter, 2019).

Antropomorfizm (İnsan Biçimcilik): Antropomorfizm terimi, eylemleri rasyonelleştirmek için cansız nesnelere veya hayvanlara insan özelliklerini atfetme eğilimi için kullanılmaktadır. Kısacası robotlarda insana benzerlik olarak tanımlanmaktadır (DiSalvo, Gemperle, Forlizzi ve Kiesler, 2002). Özellikle de insan benzeri zihinsel kapasitelere atfetmeyi içerdiğinden, hayatı cansız nesnelere atfetmenin ötesine geçmektedir (Waytz, Cacioppo ve Epley, 2010). Antropomorfizm, anlamlı sosyal etkileşimleri ve robotun insan tarafından kabul edilmesini desteklemek için esas olarak sosyal robotikte uygulanmaktadır (Duffy, 2003).

Sosyal Etki: Rashotte (2007) sosyal etkinin, bir bireyin düşünce, duygu, tutum veya davranışlarında başka bir birey veya bir grupla etkileşimden kaynaklanan değişiklik olduğunu ifade etmiştir. Sosyal etki; uyum, güç ve otoriteden farklıdır. Uyum, bir kişinin belirli bir duruma ayak uydurması; uyum sağlanan görüşe sahip olması gerekmeksizin davranışın uygun olduğunu kabul etmesidir. Güç, bir kişiyi, sonuçlarını kontrol ederek belirli bir şekilde davranmaya zorlama yeteneğidir. Otorite, ona tabi olanlar tarafından meşru olduğuna inanılan güçtür (Rashotte, 2007). Sosyal etki, insanların, içsel olarak sisteme olumlu bakmamalarına rağmen, önemli referansları olan kişilerin yapmaları gerektiğini düşündükleri takdirde, bir sistemi yararlı bulabilecekleri ve onu kullanmayı seçebilecekleri anlamına gelmektedir (Venkatesh,Morris, Davis ve Davis 2003). 
Kolaylaştırıcı Koşullar: Thompson, Higgins ve Howell(1991),Triandis 'in (1980) "Kişilerarası Davranış Modeli"ni temel alarak bireylerin bilgisayar kullanımlarına ilişkin çalışmalar yürütmüş ve bilgisayar kullanımına etki eden unsurları analiz ederek "PC Kullanım Modeli"adında yeni bir model geliştirmişlerdir. Kolaylaştırıcı koşullar kavramı özünde, kişinin bir sistemin kullanımını destekleyen organizasyonel ve teknik altyapının ne derece var olduğunu ölçümlemeye yöneliktir. Taylor ve Todd (1995) ise “Ayrıştırılmış Planlı Davranış Teorisi"nde kolaylaştırıcı koşulları iki boyutta incelemiştir. Birincisi para ve zaman gibi unsurlarla ilişkili olan kaynak kolaylaştırıcı koşullar,ikincisi ise teknolojiyle ilişkili unsurların oluşturduğu teknoloji kolaylaştırıcı koşullardır. Kolaylaştırıcı koşullar, teknoloji kabulüne yönelik model ve araştırmalarda da kullanılmıştır (Esen ve Büyük, 2014). Kolaylaştırıcı koşullar, bir kullanıcının desteğinin yeni bir teknolojiyi benimsemesi için yeterli organizasyonel ve teknik altyapının varlığı olarak tanımlanmaktadır (Venkatesh, Thong ve Xu, 2012).

Duygular: Duygular terimine ilişkin genel kabul görmüş bir tanım olmamakla birlikte, Psikoloji bilimi altında bu kavrama kuramcı ve betimleyici olarak yaklaşılmaktadır (Widen ve Russell, 2010)Solomon ve Stone (2002) duygu kavramının belirgin bir şekilde olumlu ve olumsuz duygular olarak ikiye ayrıldığını ifade etmişlerdir.İyilik, hoşnutluk, onaylama, sağlıklı olmak, zevk alma, mutluluk, doğruluk, erdem, cesaret, sakinlik, rahatlık gibi duygular olumlu/pozitif duygular olarak ele alınırken; kötülük, acı çekme, üzgün olma, hata yapma, kızgınlık, sağlıksızlık, korku gibi duygular ise olumsuz/negatif duygular olarak ele alınmaktadır (Desmet ve Schifferstein, 2008).

\section{YÖNTEM}

Çalışmanın amacı, günümüz firmalarının rekabet avantajı sağlamalarında ve rakiplerin önüne geçmelerinde en önemli yollarından olan teknolojik ve çevresel değişimlere ayak uydurmalarını kolaylaştırıcı analizlere yardımcı olmaktır. Bu değişim durumu tüketici eğilimlerine ve satın alma davranışlarına yön verebilmektedir. Dolayısıyla firmalar bu eğilimi görmeleri ve davranışlara kendi lehinde yön vermeleri için Endüstri 4.0'ın en önemli unsurlarından biri olan yapay zekâyı ön planda tutmalı ve robotik üretimi kendi kurumlarına entegre etmeleri 
gerekmektedir. Bu bağlamda bu araştırmanın amacı bireylerin yapay zekâ ve hizmet robotlarını düzenli hizmet işlemlerine entegre etme konusundaki uzun vadeli istekliliğini karakterize eden, Lu vd. (2019) tarafından geliştirilen çok boyutlu Hizmet Robotu Entegrasyon İsteklilik (HREI) ölçeğini Türkçeye uyarlamaktır. Bu uyarlama için ölçeği geliştirenlerden gerekli izinler alınmıştır. Ölçek yurt dışında birçok araştırmacı tarafından kullanılmasına rağmen ülkemizde bu ölçeği bugüne kadar, Türk kültürüne uyarlanması kapsamında yapılan herhangi bir çalışmaya rastlanılmamıştır. Bu çalışmada özellikle hizmet sektöründe faaliyet gösteren firmaların hizmet robotu entegrasyon istekliliğini ölçerek; bu ölçeğin geçerlilik ve güvenilirliğine ilişkin bulgularının bir defa daha gözden geçirilerek Türkçeye uyarlanması hedeflenmektedir.

Hizmet Robotu Entegrasyon İstekliliği ölçeği orijinalde 36 madde ve 6 faktörden oluşmaktadır. Bu kapsamda, yapılan araştırmada öncelikle 36 maddenin yer aldığ1 ölçeğin Türkçe çevirilerindeki anlam bütünlüğü gözden geçirilmiştir. Hizmet Robotu Entegrasyon İstekliliği ölçeğinin uyarlaması Brislin (1980) tarafından önerilen uyarlama yöntemine göre yapılmıştır. Bu yöntem beş temel adımı içeren bir modeldir.

1. Ölçeğin kullanılacak hedef dile çevrilmesi,

2. Hedef dile yapılan çevirinin değerlendirilmesi,

3. Kaynak dile tekrar çevrilmesi,

4. Kaynak dile yapılan tekrar çevirinin değerlendirilmesi,

5. Uzmanlarca son değerlendirmenin yapılması.

Ölçeğin Türkçeye çevirisi 3 akademisyen tarafından yapılmıştır. Her üç akademisyenin ana dilleri Türkçedir. İngilizce diline hâkim kişilerdir. Bu akademisyenlerden birinin Türkçeye ölçek uyarlama ve geliştirme konusunda çalışmaları bulunmaktadır ve yönetim ve organizasyon alanında doktora derecesine sahiptir. Diğer iki akademisyen ise yabancı dil yüksekokullarında görev yapmaktadırlar. Ölçeğin çevirisi üç ayrı akademisyen tarafından, birbirinden bağımsız olarak yapılmıştır. Yapılan Türkçe çevirilerin değerlendirilmesi yönetim ve organizasyon alanında tecrübesi olan dört akademisyen tarafından yapılmıştır. Çeviriler ayrı ayrı okunarak, her bir maddeyi anlaşılırlık, Türkçeye uygunluk, 
kullanılan kelimelerin doğruluğu ve açıklığ1 yönlerinden değerlendirmeler yapılmış ve üzerinde uzlaşılan çeviriler kullanılarak anket formu oluşturulmuştur. Ortaya çıkan ölçek daha sonra alanında uzman, doktora derecesine sahip, bugüne kadar ölçek uyarlama ve ölçek geliştirme çalışmaları yapan bu çalışmanın araştırmacılarından olan bir akademsiyen tarafından İngilizceden Türkçeye çevrilerek dil yapısı, kullanılan kelimelerin uygunluğu ve güncelliği yönlerinden kontrol edilmiş ve orijinal anketle örtüşmesine bakılmıştır. Bu son değerlendirme neticesinde ölçeğin Türkçe çevirisinin hem biçimsel hem de içerik olarak uygun olduğuna ve araştırmada kullanılabileceğine karar vermişlerdir. Bu karar sonucunda ölçeğin uyarlamasının yapılması için üç adım sırasıyla takip edilmiştir:

- Birinci adım, pilot uygulama ile geçerlik ve güvenirlik sınaması yapılmıştır.

- İkinci adım, ikinci bir örneklem ile ölçeği oluşturan maddeler için güvenilirlik incelemeleri ve keşfedici faktör analizi (KFA) ve doğrulayıcı Faktör Analizi (DFA) yapılmıştır.

- Üçüncü adımda ise, ölçeğin son hali yeni bir örnekleme uygulanarak (tekrar test), yapısal geçerlilik ve güvenilirlik incelemeleri tekrarlanarak, faktör yapısının doğrulanması ve faktör yapı geçerliğini belirlemek için KFA'dan elde edilen madde-faktör yapısı doğrulayıcı faktör analizi (DFA) ile tekrar test edilmiştir.

Analizleri gerçekleştirmek için SPSS ve AMOS programlarından yararlanılmıştır. İlgili alan yazın incelendiğinde ölçek geliştirme ve uyarlama çalışmalarında optimal örneklem büyüklükleri ile ilgili farklı araştırmacıların farklı görüşleri bulunduğu görülmektedir. Bu araştırmada Gorsuch (1974), Kline (1979) en az 100 olmalı (Akt. Çolakoğlu ve Büyükekşi, 2014: 59) önerisi benimsenmiş, her biri en az 100 ve üzeri üç örnekleme ulaşılmıştır. İzleyen bölümlerde söz konusu üç örnekleme ait betimleyici istatistikler ve gerçekleştirilen istatistiksel analizlere ilişkin bulgulara yer verilmiştir. Analizler kolayda örneklem ile gönüllü katılımcıların olduğu üç farklı örneklem üzerinde yapılmıştır. Üç farklı örneklem kullanılmasının amacı, diğerlerine göre küçük örneklemler ( $n=127$ ve $n=253$ ) üzerinde ve farklı hizmet sektörlerinde elde edilmiş faktör yapısının, geçerliliğin ve güvenirliğinin daha geniş bir örneklemde $(n=293)$ test edilebilmesi düşüncesidir. Araştırmanın 
örneklemi, Türkiyenin farklı bölgelerinde bulunan ve hizmet sektöründe faaliyet gösteren firmalarda çalışan 18 yaş ve üzeri bireylerden oluşmaktadır. Bu çalışmanın verileri 2019 yılı Haziran - Aralık ayları arasında toplandığından etik kurul izin belgesi gerekmemektedir.

\section{BULGULAR}

\subsection{Birinci Örnekleme İlişkin Bulgular}

Birinci örneklemde; 36 maddelik hizmet robotu entegrasyon isteklilik ölçeği Ege ve Marmara bölgesinde yer alan bazı illerde farklı hizmet sektörlerinde çalışan 127 katılımcıya pilot çalışma olarak uygulanmıştır. Bu örneklem ile yapılan çalışmada; ölçeği oluşturan maddelerin Türkçe dilbilgisine uygunluğu, ölçekte yer alan bazı maddelerin anlaşılmasında karşılaşılabilecek problemlerin giderilmesi ve ölçek maddelerinin düzenlenmesi hedeflenmiştir. Bu gruptaki çalışanların yaşlarına bakıldığında katılımcıların \%4,7'si 18-24 yaş arası, \%33,1'i 25 -32, \%38,6'sı 33-40, $\% 7,9^{\prime}$ un $41-48, \% 7,9^{\prime}$ un $49-56$ ve $\% 7,9^{\prime}$ un ise 57 ve üzeri yaşta olduğu görülmektedir. Katılımcıların cinsiyetine bakıldığından \%69,9'u kadın ve \%33,1'i ise erkektir. Katılımcıların \%54,3'ü evli iken \%45,7'si bekardır. Katılımcıların eğitim düzeyleri incelendiğinde, \%32,3'ü lise, \%44,1'i lisans ve \%23,6's1 lisansüstü dereceye sahiptir. Katılımcıların\%28,3'üu devlette, \%71,7'si ise özel sektörde çalışmaktadır. Katılımcıların \%5,5'i 1 yıldan az iş tecrübesine sahip iken \%11,0'1 1-3 yı1, \%20,5'i 4-6 yıl, $\% 7,9^{\prime}$ u 7-9 yıl ve \%55,1'i ise 9 yıldan fazla iş tecrübesine sahip olduklarını belirtmişleridir. Ayrıca katılımcıların \%67,7'si teknolojik bilgilerin güçle ve yeterli olduklarını ifade ederken \%32,3'ü ise zayıf olduğunu ifade etmişlerdir. Pilot uygulama ile dil ve kapsam geçerliği ile güvenirlik sınaması yapılmıştır. Birinci örneklemden sonra ölçekte bazı düzeltmeler yapılarak 36 sorudan oluşan aynı ölçek ikinci bir örnekleme uygulanmıştır.

\section{2. İkinci Örnekleme İlişkin Bulgular}

İkinci örneklem ise Ege ve Marmara bölgelerinde hizmet sektöründe faaliyet gösteren firmalarda çalışan ve rastgele seçilen 18 yaş üzeri 253 çalışan oluşturmaktadır. Bu gruptaki çalışanların yaşlarına bakıldığında katılımcıların \%5,5'i 18-24 yaş arası, \%39,0'1 25 -32, \%37,8'i 33-40, \%5,5'i 41-48, \%5,9'un 49-56 ve 
\%6,3'ü ise 57 ve üzeri yaşta olduğu görülmektedir. Katılımcıların cinsiyetine bakıldığından \%46,5'i kadın ve \%53,5'i ise erkektir. Katılımcların \%77,6'sı evli iken \%32,4'üu bekârdır. Katılımcıların eğitim düzeyleri incelendiğinde, \%30,7'si lise, $\% 48,8^{\prime}$ i lisans ve \%20,5'i lisansüstü dereceye sahiptir. Katılımcların\%31,1'i devlette, $\% 68,9^{\prime} \mathrm{u}$ ise özel sektörde çalışmaktadır. Katılımcıların \%6,3'ü 1 yıldan az iş tecrübesine sahip iken \%15,0'1 1-3 yıl, \%21,3'ü 4-6 yıl, \%7,1'i 7-9 yıl ve \%50,4'i ise 9 yıldan fazla iş tecrübesine sahip olduklarını belirtmişleridir. Ayrıca katılımcıların $\% 63,0^{\prime} 1$ teknolojik bilgilerin güçle ve yeterli olduklarını ifade ederken $\% 37,0^{\prime} 1$ ise zayıf olduğunu ifade etmişlerdir.

Keşfedici faktör analizine geçemeden verilerin Kaise-Meyer-Olkin (KMO) değerine bakılması gerekmektedir. Bu değerin 0,5'ten büyük olması ve 1'e yakın olması örneklem büyüklüğünün yeterliliği hakkında bilgi vermektedir (Durmuş, Yurtkoru ve Çinko, 2018:80; Büyüköztürk, 2018:136; Tabak, Kızıloğlu ve Türköz, 2013; Gürbüz ve Şahin, 2018:319). Diğer yandan faktör analizi yapabilmek için diğer önemli bir koşul ise Barlett'in küresellik testine ilişkin p değerinin 0,05'ten küçük olmasıdır (Karagöz,2016:879). İkinci örneklemde elde edilen verilerin faktör analizine uygun olduğunu gösteren Barlett Testi ve Kaiser-Meyer-Olkin testi sonuçları Tablo 1'de verilmiştir.

Tablo 1. KMO ve Barlett Küresellik Testleri Sonuçları

\begin{tabular}{|l|c|}
\hline Kaiser-Meyer-Olkin (KMO) & 0,858 \\
\hline Barlett Küresellik Testi & 3825,095 \\
Ki Kare İstatistiği (Anlamlılık) & $(, 000)$ \\
\hline Serbestlik Derecesi & 528 \\
\hline
\end{tabular}

Keşfedici Faktör Analizi (KFA): Keşfedici faktör analizi geliştirilen bir ölçeğin yap1 geçerliliğini test için kullanılan bir istatistiksel yöntemdir. Analizde her bir maddenin Eigen Value (öz değerinin) 1'den büyük olması ve faktör yük değerlerinin alt sınır olarak kabul edilen 0.30 'dan büyük olması gerekmekte ve bu değerin altında kalan veyahut birden fazla faktörde yer alan maddelerin ölçekten çıkarılması gerekliği ifade edilmektedir (Büyüköztürk, 2018:134). Dolayısıyla yapılan hizmet robotu entegrasyon isteklilik ölçeğinde faktör yük değeri 0,30'dan düşük olan 21 . Madde (İş arkadaşlarımın büyük bir kısmı bunları kullanacaksa, hizmetlerde robotlar gibi 
yapay zekâlı cihazları kullanırdım.) ve birden fazla faktörde yer alan 7. Madde (Yapay zekâlı cihazlar kullanırsam verimsiz kişisel temasları önleyebilirim.) ve 31. madde(Hizmetlerde robotlar gibi yapay zekâlı cihazlar bana korkutucu geliyor.) ölçeğin daha anlamlı olması için teker teker ölçekten çıkarılmış ve faktör yapısı yeniden kontrol edilmiştir. Maddelerin ortak yük değerleri Ek 1'de yer almaktadır. KFA sonucunda, 33 maddeden oluşan 6 faktörlü hizmet robotu entegrasyon isteklilik ölçeği toplam varyansın \%73,010'inin açıklamaktadır. Bu değerin \%50'yi geçiyor olması faktör analizi için önemli bir kıstas olduğu araştırmacılar tarafından ifade edilmektedir (Büyüköztürk, 2018:143; Durmuş vd., 2018:82). Faktörlerin açılanan varyans miktarları birinci faktör için \%15,478, ikinci faktör için \%14,159, üçüncü faktör için \%13,273, dördüncü faktör için \%11,956, beşinci faktör için \%11,383 ve altıncı faktör için \%6,762 olarak belirlenmiştir. Bu sonuçlar Tablo 2 ve Ek 2'de verilmiştir.

Tablo 2. Açıklanan Toplam Varyans Miktarları

\begin{tabular}{|c|c|c|c|c|c|c|}
\hline \multirow{2}{*}{ Faktör } & \multicolumn{3}{|c|}{ Başlangıç Özdĕgerleri } & \multicolumn{2}{c|}{ Faktör Yüklerinin Döndürülmüş Toplamları } \\
\cline { 2 - 6 } & Toplam & Varyans\% & $\begin{array}{c}\text { Kümülatif } \\
\text { \% }\end{array}$ & Toplam & Varyans\% & Kümülatif \% \\
\hline 1 & 12,644 & 38,316 & 38,316 & 5,108 & 15,478 & 15,478 \\
\hline 2 & 3,265 & 9,895 & 48,211 & 4,672 & 14,159 & 29,637 \\
\hline 3 & 2,678 & 8,114 & 56,325 & 4,380 & 13,273 & 42,910 \\
\hline 4 & 2,342 & 7,098 & 63,423 & 3,945 & 11,956 & 54,865 \\
\hline 5 & 1,883 & 5,705 & 69,128 & 3,756 & 11,383 & 66,248 \\
\hline 6 & 1,281 & 3,882 & 73,010 & 2,232 & 6,762 & 73,010 \\
\hline
\end{tabular}

Ölçekte yer alan maddelerin faktör dağılımlarını belirlemek için Varimax döndürme analizi yapılmıştır. Üç maddenin ölçekten çıkarılmış son haliyle verilere yeniden keşfedici faktör analizi yapılmıştır. Tablo 3'e bakıldığında ölçekte yer alan tüm maddelerin sınır kabul edilen 0,30'dan büyük olduğu görülmektedir. En düşük değerin 0,547; en yüksek değerin ise 0,876 olduğu görülmektedir. Bu da her bir maddenin değerinin yüksek ve birbirleriyle ilişkili olduğunu göstermektedir. 
Tablo 3. Faktör Analizi Sonrası Dönüştürülmüş Madde Bileşenler Matrisia

\begin{tabular}{|c|c|c|c|c|c|c|}
\hline & \multicolumn{6}{|c|}{ Faktör } \\
\hline & 1 & 2 & 3 & 4 & 5 & 6 \\
\hline Madde_1 & ,674 & & & & & \\
\hline Madde_2 & 786 & & & & & \\
\hline Madde_3 & 759 & & & & & \\
\hline Madde_4 & 782 & & & & & \\
\hline Madde_5 & 777 & & & & & \\
\hline Madde_6 & ,547 & & & & & \\
\hline Madde_8 & & 786 & & & & \\
\hline Madde_9 & & ,876 & & & & \\
\hline Madde_10 & & 837 & & & & \\
\hline Madde_11 & & ,824 & & & & \\
\hline Madde_12 & & ,836 & & & & \\
\hline Madde_13 & & 613 & & & & \\
\hline Madde_14 & & & ,730 & & & \\
\hline Madde_15 & & & ,826 & & & \\
\hline Madde_16 & & & 730 & & & \\
\hline Madde_17 & & & ,691 & & & \\
\hline Madde_18 & & & 829 & & & \\
\hline Madde_19 & & & ,673 & & & \\
\hline Madde_20 & & & ,673 & & & \\
\hline Madde_22 & & & & ,562 & & \\
\hline Madde_23 & & & &, 577 & & \\
\hline Madde_24 & & & & 749 & & \\
\hline Madde_25 & & & & 759 & & \\
\hline Madde_26 & & & & 763 & & \\
\hline Madde_27 & & & & 651 & & \\
\hline Madde_28 & & & & & ,755 & \\
\hline Madde_29 & & & & & ,842 & \\
\hline Madde_30 & & & & & ,865 & \\
\hline Madde_32 & & & & & & ,759 \\
\hline Madde_33 & & & & & & 804 \\
\hline Madde_34 & & & & & & 790 \\
\hline Madde_35 & & & & & & 806 \\
\hline Madde_36 & & & & & & ,792 \\
\hline
\end{tabular}

Bu geçerlik testleri sonucunda, hizmet robotu entegrasyon isteklilik ölçeğinin 33 maddeden ve 6 faktörden oluşan bir yapıya sahip olduğu Tablo 3’ te görülmüştür. Her bir faktörde yer alan maddeler ve her bir alt boyut için ayrı ayrı hesaplanan Cronbach Alpha iç tutarlılık değerleri Tablo 4'te sunulmuştur. Cronbach Alpha değerinin 0,70'ten büyük olması ölçeğin güvenilir olduğunu göstermektedir (Durmuş vd., 2018:89; Büyüköztürk, 2018:180; Çelik, 2016:55). Analiz sonucunda Cronbach Alfa değerlerinin tüm boyutlarda 0,70 sınırından yüksek olduğu izlenmiş, dolayısıyla ölçeğin iç tutarlık katsayısının güvenilir olduğu kabul edilmiştir. 
Tablo 4. Ölçekte Yer Alan Maddeler ve Cronbach's Alpha Değerleri

\begin{tabular}{|c|l|l|c|}
\hline $\begin{array}{c}\text { Boyut } \\
\text { Sirasi }\end{array}$ & \multicolumn{1}{|c|}{ Boyut } & \multicolumn{1}{|c|}{$\begin{array}{c}\text { Ölçekteki Madde } \\
\text { Numaras1 }\end{array}$} & $\begin{array}{c}\text { Cronbach's Alpha } \\
\text { Değeri }\end{array}$ \\
\hline 1 & F1- Performans Etkinliği & $1,2,3,4,5,6$ &, 843 \\
\hline 2 & F2- İçsel Motivasyon & $8,9,10,11,12,13$ &, 952 \\
\hline 3 & F3- Antropomorfizm (İnsan Biçimcilik) & $14,15,16,17,18,19,20$ &, 893 \\
\hline 4 & F4- Sosyal Etki & $22,23,24,25,26,27$ &, 899 \\
\hline 5 & F5- Kolaylaştırıc1 Koşullar & $28,29,30$ &, 782 \\
\hline 6 & F6- Duygular & $32,32,34,35,36$ &, 966 \\
\hline Toplam & \\
\hline
\end{tabular}

Keşfedici faktör analizi sonucunda ölçekte kalan her bir maddenin ölçeğin tamamıla olan korelasyon ilişkisini belirlemek için madde-toplam korelasyon ilişkisine dayalı madde analizi yapılmıştır. Sonuçlar Ek 3'te yer almaktadır. Bir maddenin madde-toplam korelasyon katsayısı değerinin 0,20' den küçük veya negatif olması, madde güvenirliği ve iç tutarlılığın olmadığını göstermektedir. Dolayısıyla bu maddelerin ölçekten çıkarılması gerektiği ifade edilmektedir (Büyüköztürk, 2007:124). Ek 3 incelendiğinde en küçük değerin 0,34 en büyük değerin ise 0,78 olduğu görülmektedir. KFA sonrası ölçeğin Cronbach Alpha değeri 0,941 bulunmuştur. Ayrıca eğer madde silinirse Cronbach Alpha değerinin ne kadar değişebileceği de Ek 3'te sunulmuştur. Ek 3 incelendiğinde bu değerin 0,70'ten büyük olduğu görülmektedir. Bundan dolayı KFA'dan sonra herhangi bir maddenin çıkarılmasına ihtiyaç duyulmamıştır. Güvenirlik ve geçerlik analizleri sonucunda 33 maddeden oluşan ve orijinaldeki gibi 6 faktörlü bir ölçek yapısı elde edilmiştir.

Hizmet robotu entegrasyon isteklilik ölçeğinin yapı geçerlilik ve güvenirlik değerlerini elde etmek üzere yapılan ilk iki uygulama neticesinde, ölçek ile ilgili bu değerlerin kabul edilebilir düzeyde olması sonucu, elde edilen faktör yapısının, doğrulayıcı faktör analiziyle (DFA) incelenmesi ve yapısal modellerin test edilmesi gerekmektedir.

Doğrulayıcı Faktör Analizi (DFA): Doğrulayıcı faktör analizi, daha önce bir örnekleme uygulanmış veya KFA yapılmış bir ölçeğin yapısının toplanan başka veriler ile doğrulanıp doğrulanmadığını tespit etmek amacıyla kullanılmaktadır. DFA'da ilişkisiz model, tek faktörlü model, birinci düzey ve ikinci düzey çok 
faktörlü model olmak üzere dört temel ölçüm modeli test edilmektedir (Meydan ve Şeşen, 2015:57; Karagöz, 2016:1003). Bu dört modelde uyum iyiliği değerleri kabul edilebilir seviyede çıkan model doğrultusunda ölçeğin faktör yapısı belirlenir. Çalışmadan elde edilen veriler neticesinde diğer üç modele göre ikinci düzey çok faktörlü modelinin uyum iyiliği değerlerinin kabul edilebilir seviyede çıktığı görülmüştür. İkinci düzey faktör analizi, oluşan faktörler arasındaki ilişkiyi modele dahil edip daha sonra da bu faktörler daha kapsayıcı bir faktör altında birleştiren modeldir (Meydan ve Şeşen, 2015:83). Bu da modelde yer alan faktörlerin birbirleriyle ilişkili oluğunu ve tüm faktörleri kapsayan tek bir faktör olduğunu göstermektedir. Bu araştırmada uyum iyiliği değerleri kabul edilebilir seviyede çıkan model "ikinci düzey çok faktörlü model" Şekil 1'de sunulmuştur $\left(\Delta \chi^{2}=750,059, \mathbf{s d}=\right.$ $489 \chi^{2} / \mathrm{sd}=1,53, \mathrm{NFI}=0,91, \mathrm{CFI}=0,94 \mathrm{GFI}=0,92, \mathrm{AGFI}=0,90, \mathrm{RMR}=0,03 \mathrm{RMSEA}=0,04$ ve $p=, 000)$.

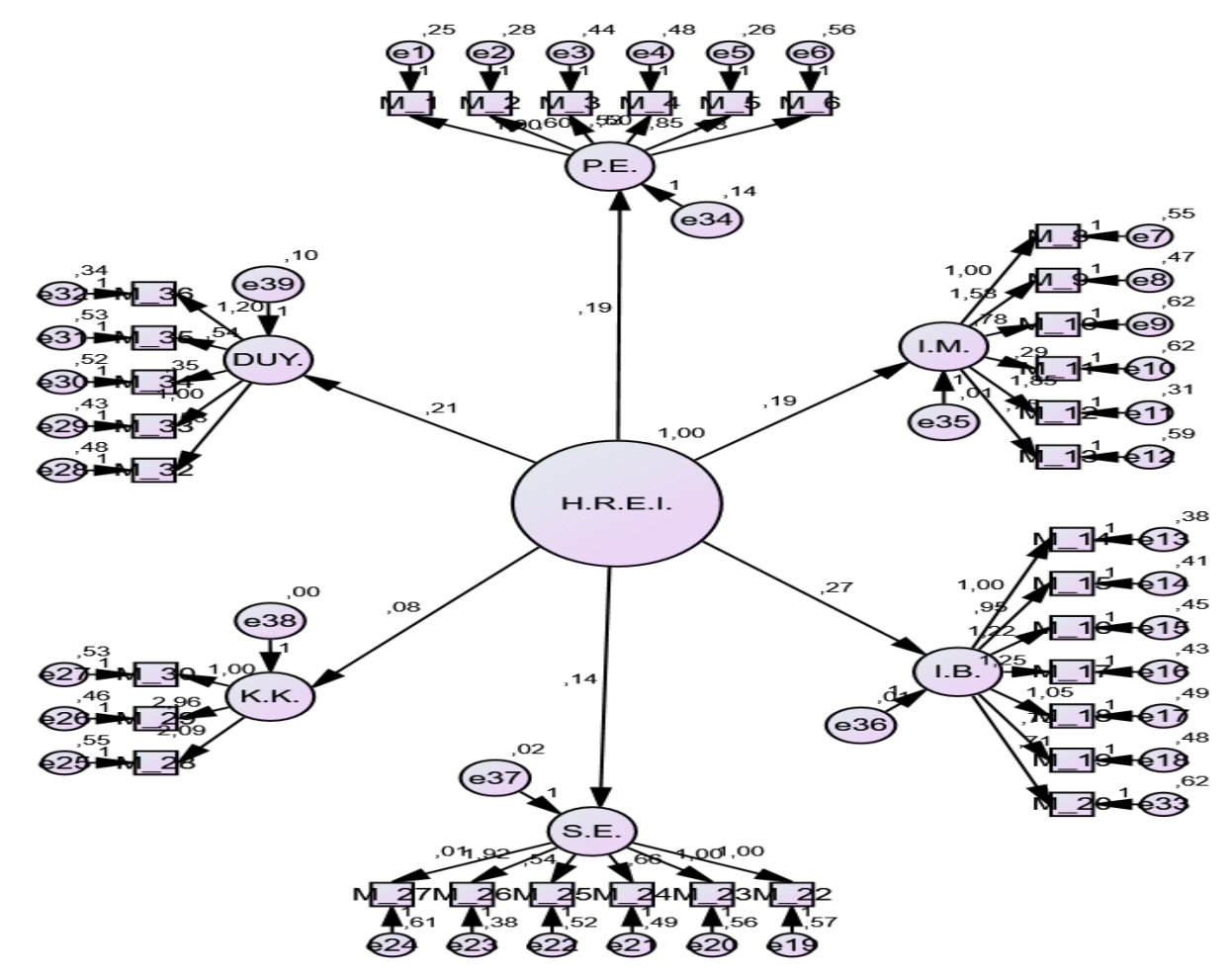

Şekil 1. Doğrulayıcı Faktör Analizi AMOS Diyagramı (II. Örneklem) 


\section{3. Üçüncü Örnekleme İlişkin Bulgular}

İlk iki örneklem sonucunda 33 maddelik hizmet robotu entegrasyon isteklilik ölçeğin son hali üçüncü bir örnekleme uygulanmıştır. Bu örneklemde Marmara ve Ege bölgelerinde yer alan ve farklı hizmet sektörlerinde faaliyet gösteren firmalarda çalışanlar yer almaktadır. Son örneklem ile ilgili betimleyici istatistikler Tablo 5 'te yer almaktadir.

Tablo 5. III. Örnekleme Ait Betimleyici Özellikler ( $n=293)$

\begin{tabular}{|c|c|c|c|}
\hline Demografik Değişken & Kategori & $\mathbf{N}$ & $\%$ \\
\hline \multirow{2}{*}{ Cinsiyet } & Kadın & 121 & 41,3 \\
\hline & Erkek & 172 & 58,7 \\
\hline \multirow{6}{*}{ Yaş } & 18-24 yaş arası & 46 & 15,7 \\
\hline & $25-32$ yaş arası & 89 & 30,4 \\
\hline & $33-40$ yaş arası & 67 & 22,9 \\
\hline & $41-48$ yaş arası & 35 & 11,9 \\
\hline & 49-56 yaş arası & 30 & 10,2 \\
\hline & 47 ve üzeri & 26 & 8,9 \\
\hline \multirow{2}{*}{ Medeni Durum } & Evli & 215 & 73,4 \\
\hline & Bekar & 78 & 26,6 \\
\hline \multirow[b]{3}{*}{ Ĕgitim Düzeyi } & Lise & 135 & 46,1 \\
\hline & Lisans & 116 & 39,6 \\
\hline & Lisansüstü & 42 & 14,3 \\
\hline \multirow{2}{*}{ Çalışılan Kurum } & Devlet & 97 & 33,1 \\
\hline & Özel & 196 & 66,9 \\
\hline \multirow{5}{*}{ İş Tecrübesi } & 1 yıldan az & 47 & 16,1 \\
\hline & 1-3 y1l arası & 66 & 22,5 \\
\hline & 4-6 y1l arası & 92 & 31,4 \\
\hline & 7-9 y1l aras1 & 52 & 17,7 \\
\hline & 10 yıl ve üzeri & 36 & 12,3 \\
\hline \multirow{2}{*}{ Algilanan Teknolojik Bilgi } & Yeterli & 236 & 80,5 \\
\hline & Zayıf & 57 & 19,5 \\
\hline
\end{tabular}

Doğrulayıcı Faktör Analizi Tekrarı: Son örneklemde daha önce faktör yapısı belirlenmiş hizmet robotu entegrasyon isteklilik ölçeğine DFA tekrar yapılmıştır. Her bir faktörün güvenirliği Cronbach Alfa ile ölçülmüş ve bu değerler, F1, F2, F3, F4, F5 ve F6 için sırasılyla $0,796,0,900,0,797,0,828,0,771$ ve 0,946 ; ölçeğin tamamı için ise 0,924 olarak hesaplanmıştır. Söz konusu güvenirlik değerleri analiz için oldukça yüksektir.

Eğer boyutlarda maddeler arası korelâsyon yüksek ve pozitif ise, boyutları oluşturan maddelerin birbirine benzer davranış sergilediği ve bundan dolayı testin iç tutarlığının da yüksek olduğu belirtilmektedir (Büyüköztürk, 2007:170). Analizde 
korelasyon katsayılarının 0,62 ile 0,79 arasında \%1 düzeyinde yüksek düzeyde gerçekleştiği izlenmiş sonuçlar Tablo 6’ da sunulmuştur.

Tablo 6. Faktör Korelasyonları

\begin{tabular}{|ll|l|l|l|l|l|l|}
\hline & & F1 & F2 & F3 & F4 & F5 & F6 \\
\hline F1 & Pearson Korelasyon & 1 & & & & & \\
& Sig. (2-kuyruklu) & & & & & \\
& N & 293 & & & & \\
F2 & Pearson Korelasyon &, $764^{* *}$ & 1 & & & \\
& Sig. (2-kuyruklu) &, 000 & & & & \\
& N & 293 & 293 & & & \\
F3 & Pearson Korelasyon &, $756^{* *}$ &, $733^{* *}$ & 1 & & & \\
& Sig. (2-kuyruklu) &, 000 &, 000 & & & \\
& N & 293 & 293 & 293 & & & \\
F4 & Pearson Korelasyon &, $721^{* *}$ &, $740^{* *}$ &, $766^{* *}$ & 1 & & \\
& Sig. (2-kuyruklu) &, 000 &, 000 &, 000 & & & \\
& N & 293 & 293 & 293 & 293 & & \\
F5 & Pearson Korelasyon &, $670^{* *}$ &, $632^{* *}$ &, $624^{* *}$ &, $647^{* *}$ & 1 & \\
& Sig. (2-kuyruklu) &, 000 &, 000 &, 000 &, 000 & & \\
& N & 293 & 293 & 293 & 293 & 293 & \\
F6 & Pearson Korelasyon &, $755^{* *}$ &, $736^{* *}$ &, $761^{* *}$ &, $779^{* *}$ &, $711^{* *}$ & 1 \\
& Sig. (2-kuyruklu) &, 000 &, 000 &, 000 &, 000 &, 000 & \\
& N & 293 & 293 & 293 & 293 & 293 & 293 \\
\hline
\end{tabular}

${ }^{* *}$ Korelasyon 0.01 düzeyinde anlamlıdır (2-kuyruklu).

Modifikasyon değerleri yüksek olan ve aynı faktörde yer alma şartıyla bazı maddeler arasında kovaryanslar oluşturularak iyileştirme yapılabilir (Karagöz, 2016:1015). Bu modelde de uyum iyiliği değerlerini azaltan bazı değişkenler belirlenmiş, artık değerler arasında modifikasyon değerleri yüksek olanlar için yeni kovaryanslar oluşturulmuştur (e4-e5; e13-e14; e18-e33). Üçüncü örneklemden elde edilenler veriler ile yapılan ikinci düzey doğrulayıcı faktör analizi sonucunda, elde

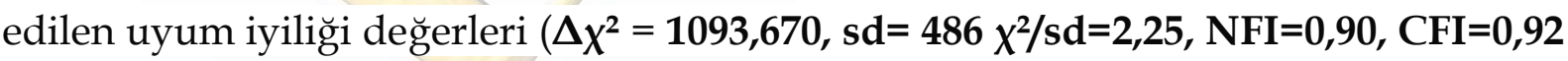
$\mathrm{GFI}=0,91, \mathrm{AGFI}=0,89, \mathrm{RMR}=0,04 \mathrm{RMSEA}=0,05$ ve $\mathrm{p}=, 000$ ) olarak bulunmuş ve standartlaştırılmış tahmini değerlerin pozitif olduğu Şekil 2' de gösterilmiştir. 


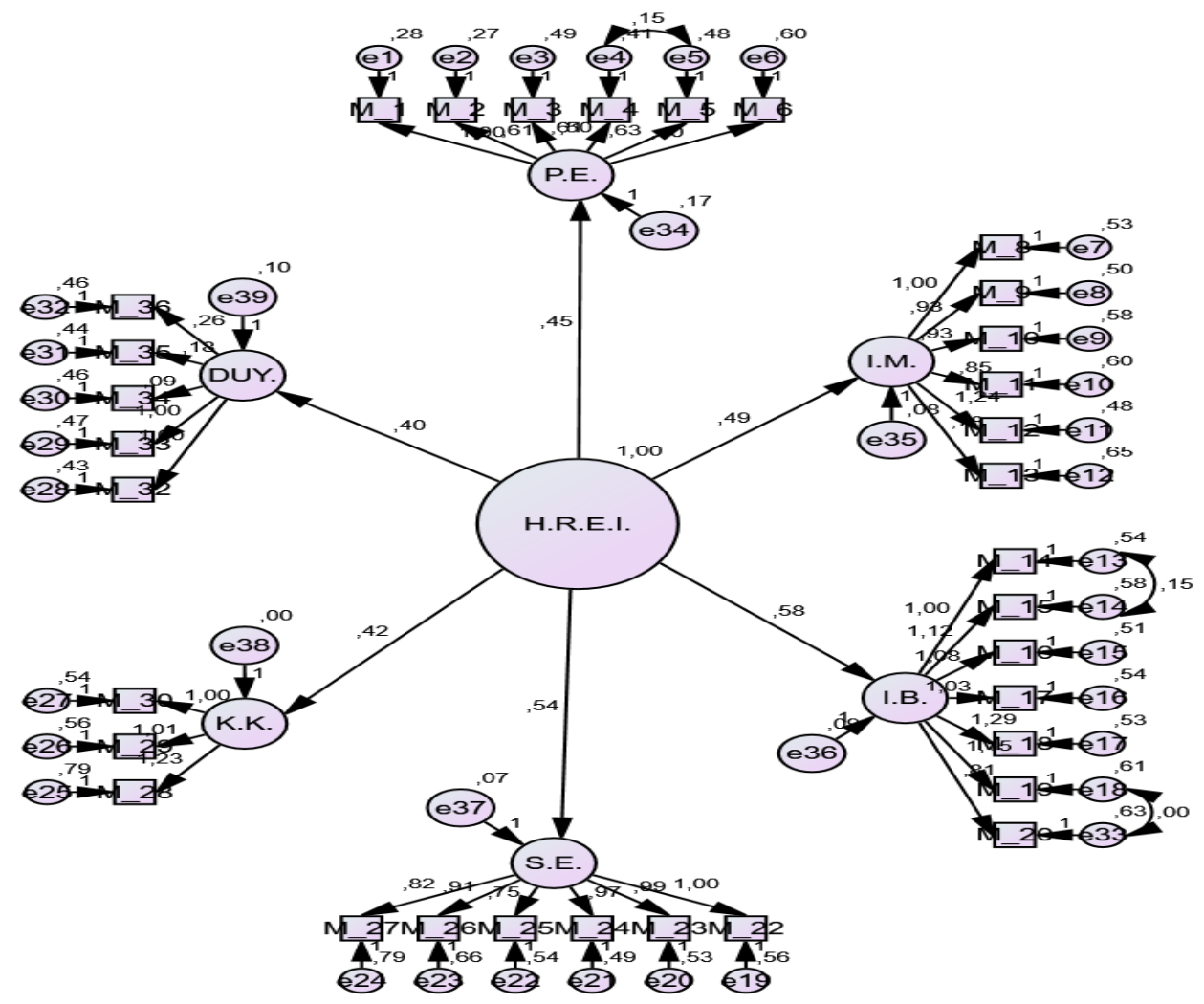

Şekil 2.Doğrulayıcı Faktör Analizi AMOS Diyagramı (III. Örneklem)

Yapılan bu son işlem sonucunda orijinaldeki gibi 6 faktörlü ve 33 maddeli bir ölçek elde edilmiştir. Hizmet robotu entegrasyon isteklilik ölçeğinin Türkçeye uyarlanmış faktör yapısı ve bu faktörleri oluşturan maddelerin son hali Ek-4'te, İngilizce dilinde orijinal hali ise Ek-5'te yer almaktadır.

\section{SONUÇ}

21. yy (dijital çă̆) işletmelerin gelişimleri, değişimleri hatta dönüşümleri hızla yaşadığı bir döneme tanıklık etmektedir. İşletmeler başta üstün rekabet avantajı sağlayabilmek dolayısıyla kendilerini yaşanan gelişmelere ayak uydurabilecek seviyeye getirmek ve çalışanlardan daha fazla verim alabilmek adına işleri kolaylaştırabilmek için üretim ve hizmetlerinde otomatikleşme ve robotikleşme yolunda ilerlemektedir.

Dijitalleşme döneminin getirisi olan otomatikleşme ve robotikleşme, çalışanlar açısından farklı değerlendirilebilmektedir. Bu çalışmada hizmet robotu olarak ele alınan yapay zekâlı yardımcılar çalışanların bir kısmı için kullanımı kolay ve rahat, eğlenceli, keyifli iken; bir kısmı için de zor ve sıkıcı, keyifsizdir. İşletmelerin 
geleceklerini her yönden planlayabilmek ve bu ayrımı anlayabilmek adına Lu vd. (2019) trafından geliştirilen ve bu çalışma ile Türkçeye uyarlanan Hizmet Robotu Entegresyonu İstekliliği Ölçeği'nin hem akademik hem de sektörel bazda fayda sağlayacağı düşünülmektedir. Ölçek orjinalinde 36 madde ve 6 faktörden oluşmaktadır. Farklı hizmet sektörlerinde faaliyet gösteren 673 çalışanın gönüllü katıldığı üç örneklem ile elde edilen veriler analiz edilmiştir. Ölçeğin yapı geçerliğini belirlemek için keşfedici ve doğrulayıcı faktör analizleri yapılmıştır. Toplam varyansın\%73,01'ini açılayan ve orijinaldeki gibi 6 faktörlü bir yapı elde edilmiştir. Fakat üç madde uyum değerleri kabul edilen değer aralığında çıkmadığı için ölçekten sırasıyla teker teker çıkarılmıştır. Elde edilen bulgular Hizmet Robotu Entegrasyonu İsteklilik Ölçeği'nin Türkçe formunun farklı sektörlerde faaliyet gösteren kurum ve kuruluşlar için kullanılabilecek kabul edilebilir değerlerde güvenilir ve geçerli bir ölçme aracı olduğu söylenebilir. Ölçeğin son hali Ek-4'te yer almaktadir.

Gelecekte yapılacak çalışmalar için araştırmacılara 1şık tutacak olan bu ölçek bir yandan da işletmenin kendini tanıması, çalışanlarını değerlendirmesi açısından önemli bir konum elde edeceği düşünülmektedir. Mevcut insan kaynağının planlamasını ve eğitim analizini gerçekleştirirken yararlanılabileceği gibi yapılan uzun vadeli stratejik planlamada insan kaynağının yetkinliklerinin nasıl olması gerektiğine yön verebilecek bir analiz metodu olarak da kullanılabileceği düşünülmektedir.

Araştırmanın kısıtları arasında Marmara ve Ege Bölgesi ile sınırlı bir kitleye ulaşılması ve değerlendirilen kişi sayısının 673 olması sayılabilmektedir. Diğer bölgelerdeki çalışanların da değerlendirilmesi, kuşaklar arası farklılıkların tespiti için bir ayrım ile değerlendirilmesi, farklı değişkenler ile ilişki ve etki saptaması yapılması önerilerimiz arasında yer almaktadır.

Gelişmiş teknolojilerin benimsenmesi endüstri ve toplum için faydalı olacaktır, ancak sağlam yapay zekâlı teknolojik sistem gereksinimlerini belirlemek ve bunları doğru şekilde uygulamak için daha fazla araştırmaya ihtiyaç vardır. Yapay 
sağlayıcı önemli unsurlar arasındadır. Aynı zamanda yapay zekâ teknolojisi ne kadar hızlı ilerlerse, teknik araştırmaya yatırım yapmak için mevcut kaynaklar da o kadar fazla olacaktır. 


\section{KAYNAKÇA}

Belanche, D., Casaló, L. V, Flavián, C., \& Schepers, J. (2020). Service robot implementation: a theoretical framework and researcha genda. The Service Industries Journal, 40(3-4), 203-225. https://doi.org/10.1080/02642069.2019.1672666.

Brislin, R. W. (1980). Cross-cultural research methods. In Environment and culture (pp. 47-82). Springer, Boston, MA.

Büyüköztürk, Ş. (2007). Sosyal Bilimler İçin Veri Analizi El Kitabı (Sekizinci Baskı). Ankara: Pegem Akademi.

Büyüköztürk, Ş. (2018). Sosyal Bilimler İçin Veri Analizi El Kitabı (Yirmi Dördüncü Baskı). Ankara: Pegem Akademi.

Byrne, B. M. (2010). Structural equation modeling with AMOS: basic concepts, applications, and programming (multi variate applications series). New York: Taylor \& Francis Group, 396, 73-84.

Çelik, Y. (2016). SPSS ile İstatistik, Biyoistatistik ve Modern Bilimsel Araştırma. İstanbul: Hünkar Ofset

Çolakoğlu, Ö. M., \& Büyükekşi, C. (2014). Açımlayıcı faktör analiz sürecini etkileyen unsurların değerlendirilmesi. Karaelmas Eğitim Bilimleri Dergisi, 2(1), 58-64.

Desmet, P. M. A. \& Schifferstein, H. N. J. (2008). Sources of positive and negative emotions in food experience. Appetite, 50(2-3), 290-301.

DiSalvo, C. F., Gemperle, F., Forlizzi, J., \& Kiesler, S. (2002). All Robots Are Not Created Equal: The Design and Perception of Humanoid Robot Heads. Proceedings of the 4th Conference on Designing Interactive Systems: Processes, Practices, Methods, and Techniques, 321-326. New York, NY, USA: Association for Computing Machinery. https://doi.org/10.1145/778712.778756

Duffy, B. R. (2003). Anthropomorphism and the social robot. Robotics and Autonomous Systems, 42(3), 177-190. https://doi.org/10.1016/S0921-8890(02)00374-3

Durmuş, B., Yurtkoru S. \& Çinko M. (2018). Sosyal Bilimlerde SPSS'le Veri Analizi (Yedinci Basım). İstanbul: Beta Basım Yayın

Eberl, U. (2019). Akıllı Makineler - Yapay Zeka Hayatımızı Nasıl Değiştiriyor (1st ed.; çev: Levent Tayla, ed.). İstanbul: Paloma Yayınevi.

Esen, M.,\& Büyük, K. (2014). Teknoloji kabul modeli bağlaminda elektronik belge yönetim sisteminin incelenmesi: yükseköğretim kurulu örneği. Dumlupınar Üniversitesi Sosyal Bilimler Dergisi, (42), 313326.

Retrieved

from

https://earsiv.anadolu.edu.tr/xmlui/bitstream/handle/11421/11217/11217.pdf?sequence=1\&isAllo $\underline{w e d}=\mathrm{y}$ 
Frey, C. B.,\& Osborne, M. (2015). Technology at Work: The Future of Innovation and Employment. In Manufacturing Engineer. Oxford, England. https://doi.org/10.1049/me:19900029

Gursoy, D., Chi, O. H., Lu, L., \& Nunkoo, R. (2019). Consumers acceptance of artificially intelligent (AI) device use in service delivery. International Journal of Information Management, 49, 157-169. https://doi.org/10.1016/j.ijinfomgt.2019.03.008

Gürbüz S. \& Şahin F. (2018). Sosyal Bilimlerde Araştırma Yöntemleri (Beşinci Baskı). Ankara:Seçkin Akademik ve Mesleki Yayınlar

Huang, M.-H., \& Rust, R. T. (2018). Artificial Intelligence in Service. Journal of Service Research, 21(2), 155-172. https://doi.org/10.1177/1094670517752459

Jones, J. L. (2006). Robots at the tipping point: the road to iRobot Roomba. IEEE Robotics $\mathcal{E}$ Automation Magazine, 13(1), 76-78. https:/ / doi.org/10.1109/MRA.2006.1598056

Karagöz, Y. (2016). SPSS 23 ve AMOS 23 uygulamalı istatistiksel analizler. Nobel Akademik Yayıncilık. Klíma, I. (2001). Karel Čapek: Life and work. Catbird Press. Retrieved from https:/ / books.google.com/books?hl=tr\&lr=\&id=14i09o0QkCgC\&oi=fnd\&pg=PR7\&ots=M3Qs400OV $\underline{\mathrm{d} \& s i g=q Q C N 6 k W T-N r K Z D u u B s W-m K Q 81 z 8}$

Kuo, C.-M., Li-Cheng, C., \& Tseng, C.-Y. (2017). Investigating an innovative service with hospitality robots. International Journal of Contemporary Hospitality Management, 29(5), 1305-1321. https://doi.org/10.1108/IJCHM-08-2015-0414

Lemon, O., \& Pietquin, O. (2012). Data-Driven Methods for Adaptive Spoken Dialogue Systems: Computational Learning for Conversational Interfaces. Springer New York. Retrieved from https:/ / books.google.com.tr/books?id=d9VmX_zZuSAC

Lin, H., Chi, O. H., \& Gursoy, D. (2020). Antecedents of customers' acceptance of artificially intelligent robotic device use in hospitality services. Journal of Hospitality Marketing \& Management, 29(5), 530-549. https://doi.org/10.1080/19368623.2020.1685053

Lu, L., Cai, R., \& Gursoy, D. (2019). Developing and validating a service robot integration willingness scale. International Journal of Hospitality Management, 80, 36-51. https://doi.org/10.1016/j.ijhm.2019.01.005

McCarthy, J. (2007). What is artificial intelligence? Basic Questions. Computer Science Department, Stanford University. https://stanford.io/21So373.

McCarthy, J., Minsky, M., Rochester, N., \& Shannon, C. E. (2006). A Proposal for the Dartmouth Summer Research Project on Artifcial Intelligence. AI Magazine, 27. 
Meydan, C. H. \& Şeşen, H. (2015). Yapısal eşitlik modellemesi AMOS uygulamaları. Detay Yayıncılık. 2.Bask1

Oistad, B. C., Sembroski, C. E., Gates, K. A., Krupp, M. M., Fraune, M. R., \& Šabanović, S. (2016). Colleague or Tool? Interactivity Increases Positive Perceptions of and Willingness to Interactwith a Robotic Coworker BT -SocialRobotics (A. Agah, J.-J. Cabibihan, A. M. Howard, M. A. Salichs, \& H. He, eds.). Cham: Springer International Publishing.

Oudeyer, P. Y., Kaplan, F.,\& Hafner, V. V. (2007). Intrinsic motivation systems for autonomous mental development. IEEE Transactions on Evolutionary Computation, 11(2), 265-286.

Parisi, G. I., Kemker, R., Part, J. L., Kanan, C.,\& Wermter, S. (2019). Continual life long learning with neural networks: A review. Neural Networks, 113, 54-71.

Pinillos, R., Marcos, S., Feliz, R., Zalama, E., \& Gómez-García-Bermejo, J. (2016). Long-term assessment of a service robot in a hotel environment. Robotics and Autonomous Systems, 79, 40-57. https://doi.org/10.1016/j.robot.2016.01.014

Prentice, C.,\&Nguyen, M. (2020). Engaging and retaining customers with AI and employee service. Journal of Retailing and Consumer Services, 56, 102186. https:// doi.org/10.1016/j.jretconser.2020.102186

Rashotte, L. (2007). Social Influence. The Blackwell Encyclopedia of Sociology. https://doi.org/doi:10.1002/9781405165518.wbeoss154

Sentker, A. (2015). Mist an Bauer: Muss Aufs Feld. Werackert, erzeugt Daten. Und werdiesezulesenversteht, bekommtdiedickeren Kartoffeln. Die Zeit, 44, 35-36.

Severinson-Eklundh, K., Green, A., \& Hüttenrauch, H. (2003). Social and collaborative aspects of interaction with a service robot. Robotics and Autonomous Systems, 42(3), 223-234. https://doi.org/10.1016/S0921-8890(02)00377-9

Shi, X., Jason, S., \& Mark, A. (2020). How will service robots redefine leadership in hotel management? A Delphi approach. International Journal of Contemporary Hospitality Management, 32(6), 2217-2237. https://doi.org/10.1108/IJCHM-05-2019-0505

Solomon, R. C., \& Stone, L. D. (2002). On "positive" and "negative" emotions. Journal for the Theory of Social Behaviour, 32(4).

Tabak, A., Kızıloğlu, A. \& Türköz, T. (2013). Örtülü liderlik ölçeği geliştirme çalışması. Middle East Technical University Studies in Development, 40(1), 97-138.

Taylor, S. \& Todd, P. A. (1995). Understanding Information Technology Usage: A Test of Competing Models. Information Systems Research, 6, 144-176. 
Thompson, R. L., Higgins, C. A., \& Howell, J. M. (1991). Personal Computing: Toward a Conceptual Model of Utilization. MIS Quaterly, 126-143. https://doi.org/10.2307/249443

Triandis, H. C. (1980). Values, Attitudes, and Interpersonal Behavior. Nebraska Symposium on Motivation. Nebraska Symposium on Motivation, 27, 195-259.

Triebel, R., Arras, K., Alami, R., Beyer, L., Breuers, S., Chatila, R., \&Zhang, L. (2016). SPENCER: A Socially Aware Service Robot for Passenger Guidance and Help in Busy Airports BT - Fieldand Service Robotics: Results of the 10th International Conference (D. S. Wettergreen\& T. D. Barfoot, Eds.). Cham: Springer International Publishing. https:// doi.org/10.1007/978-3-319-27702-8_40

Turing, A. M. (2009). Computing Machinery and Intelligence BT -Parsing the Turing Test: Philosophical and Methodological Issues in the Quest for the Thinking Computer (R. Epstein, G. Roberts, \& G. Beber, Eds.). Dordrecht: Springer Netherlands. https://doi.org/10.1007/978-1-4020-6710-5_3

Tussyadiah, I. (2020). A review of research in to automation in tourism: Launching the Annals of Tourism Research Curated Collection on Artificial Intelligence and Robotics in Tourism. Annals of Tourism Research, 81, 102883. https://doi.org/10.1016/j.annals.2020.102883

VanDoorn, J., Mende, M., Noble, S. M., Hulland, J., Ostrom, A. L., Grewal, D., \& Petersen, J. A. (2016). Domo Arigato Mr. Roboto: Emergence of Automated Social Presence in Organizational Frontlines and Customers' Service Experiences. Journal of Service Research, 20(1), 43-58. https://doi.org/10.1177/1094670516679272

Venkatesh, V., Morris, M. G., Davis, G. B., \& Davis, F. D. (2003). User Acceptance of Information Technology: Toward a Unified View. MIS Quarterly, 27(3), 425-478. https://doi.org/10.2307/30036540 Venkatesh, V., Thong, J. Y. L., \& Xu, X. (2012). Consumer Acceptance and Use of Information Technology: Extending the Unified Theory of Acceptance and Use of Technology. MIS Quarterly, 36(1), 157-178. https://doi.org/10.2307/41410412

Waytz, A., Cacioppo, J., \& Epley, N. (2010). Who Sees Human?: The Stability and Importance of Individual Differences in Anthropomorphism. Perspectives on Psychological Science, 5(3), 219-232. https://doi.org/10.1177/1745691610369336

Widen, S. C., \& Russell, J. A. (2010). Descriptive and prescriptive definitions of emotion. Emotion Review, 2(4), 377-378.

You, S., \& Robert Jr., L. P. (2018). Human-Robot Similarity and Willingness to Work with a Robotic Co-Worker. Proceedings of the 2018 ACM/IEEE International Conference on Human-Robot Interaction, 251260. New York, NY, USA: Associationfor Computing Machinery. https://doi.org/10.1145/3171221.3171281 


\section{İnternet Kaynakları}

Akın Robotics (2020). Erişim adresi: https://www.akinrobotics.com/tr/

Asimo (2020). Erişim adresi: https://honda.com.tr/asimo

Beyond Robotics (2020). Erişim adresi: http://beyondrobotics.com.tr/

Icub (2020). Erişim adresi: https://icub.iit.it/

International Organization for Standardization (2012). Erişim adresi:

https://www.iso.org/obp/ui/\#iso:std:iso:8373:ed-2:v1:en

Kuka (2020). Erişim adresi: https://www.welt.de/139426894b

Mercedes (2020). Erişim adresi: https://www.mercedes-benz.com/en/innovation/autonomous/thenew-s-class-intelligent-drive-next-level/

Roboy (2020). Erişim adresi: https://roboy.org/

Sophia (2020). Erişim adresi: https://www.hansonrobotics.com/sophia/

The Room Service Robots (2015). Erişim adresi: https://www.pcmag.com/news/the-room-servicerobots-have-arrived 


\section{EKLER}

Ek 1. Maddelerin Ortak Yük Değerleri

\begin{tabular}{|c|c|c|}
\hline & Başlangıç (Initial) & Çıkarım (Extraction) \\
\hline Madde_1 & 1,000 &, 573 \\
\hline Madde_2 & 1,000 & 686 \\
\hline Madde_3 & 1,000 & 677 \\
\hline Madde_4 & 1,000 & 665 \\
\hline Madde_5 & 1,000 & 713 \\
\hline Madde_6 & 1,000 & 457 \\
\hline Madde_8 & 1,000 & 814 \\
\hline Madde_9 & 1,000 & 901 \\
\hline Madde_10 & 1,000 & 871 \\
\hline Madde_11 & 1,000 & 878 \\
\hline Madde_12 & 1,000 & 900 \\
\hline Madde_13 & 1,000 &, 586 \\
\hline Madde_14 & 1,000 & 667 \\
\hline Madde_15 & 1,000 & 759 \\
\hline Madde_16 & 1,000 &, 578 \\
\hline Madde_17 & 1,000 & 610 \\
\hline Madde_18 & 1,000 & 748 \\
\hline Madde_19 & 1,000 & 664 \\
\hline Madde_20 & 1,000 & 610 \\
\hline Madde_22 & 1,000 & 657 \\
\hline Madde_23 & 1,000 &, 542 \\
\hline Madde_24 & 1,000 & 715 \\
\hline Madde_25 & 1,000 & 803 \\
\hline Madde_26 & 1,000 & 756 \\
\hline
\end{tabular}




\begin{tabular}{|l|l|l|}
\hline Madde_27 & 1,000 & 642 \\
\hline Madde_28 & 1,000 &, 696 \\
\hline Madde_29 & 1,000 &, 803 \\
\hline Madde_30 & 1,000 & 792 \\
\hline Madde_32 & 1,000 &, 816 \\
\hline Madde_33 & 1,000 &, 867 \\
\hline Madde_34 & 1,000 &, 849 \\
\hline Madde_35 & 1,000 &, 905 \\
\hline Madde_36 & 1,000 & 893 \\
\hline Extraction Method: Principal & & \\
\hline Component Analysis. & & \\
\hline
\end{tabular}


Ek 2. Açıklanan Toplam Varyans Miktarları

\begin{tabular}{|c|c|c|c|c|c|c|c|c|c|}
\hline \multirow[b]{2}{*}{ Faktör } & \multicolumn{3}{|c|}{ Başlangıç Özdeğerleri } & \multicolumn{3}{|c|}{$\begin{array}{l}\text { Kare Yüklerin Ekstraksiyon } \\
\text { Toplamları }\end{array}$} & \multicolumn{3}{|c|}{$\begin{array}{l}\text { Faktör Yüklerinin } \\
\text { Döndürülmüş Toplamları }\end{array}$} \\
\hline & Toplam & Varyans $\%$ & Kümülatif \% & Toplam & Varyans $\%$ & Kümülatif \% & Toplam & Varyans $\%$ & Kümülatif \% \\
\hline 1 & 12,644 & 38,316 & 38,316 & 12,644 & 38,316 & 38,316 & 5,108 & 15,478 & 15,478 \\
\hline 2 & 3,265 & 9,895 & 48,211 & 3,265 & 9,895 & 48,211 & 4,672 & 14,159 & 29,637 \\
\hline 3 & 2,678 & 8,114 & 56,325 & 2,678 & 8,114 & 56,325 & 4,380 & 13,273 & 42,910 \\
\hline 4 & 2,342 & 7,098 & 63,423 & 2,342 & 7,098 & 63,423 & 3,945 & 11,956 & 54,865 \\
\hline 5 & 1,883 & 5,705 & 69,128 & 1,883 & 5,705 & 69,128 & 3,756 & 11,383 & 66,248 \\
\hline 6 & 1,281 & 3,882 & 73,010 & 1,281 & 3,882 & 73,010 & 2,232 & 6,762 & 73,010 \\
\hline 7 & 975 & 2,954 & 75,964 & & & & & & \\
\hline 8 & 935 & 2,833 & 78,797 & & & & & & \\
\hline 9 & 794 & 2,406 & 81,202 & & & & & & \\
\hline 10 & 700 & 2,122 & 83,324 & & & & & & \\
\hline 11 & 649 & 1,968 & 85,292 & & & & & & \\
\hline 12 &, 509 & 1,544 & 86,835 & & & & & & \\
\hline 13 & 474 & 1,437 & 88,273 & & & & & & \\
\hline 14 & 438 & 1,326 & 89,599 & & & & & & \\
\hline 15 & 386 & 1,169 & 90,768 & & & & & & \\
\hline 16 & 358 & 1,085 & 91,853 & & & & & & \\
\hline 17 & 346 & 1,049 & 92,902 & & & & & & \\
\hline 18 & 286 & 868 & 93,770 & & & & & & \\
\hline 19 & 278 & 842 & 94,612 & & & & & & \\
\hline 20 & 273 & 828 & 95,439 & & & & & & \\
\hline 21 & 228 & 692 & 96,131 & & & & & & \\
\hline 22 & 205 & 621 & 96,752 & & & & & & \\
\hline 23 & 167 & 506 & 97,258 & & & & & & \\
\hline
\end{tabular}




\begin{tabular}{|c|l|l|l|l|l|l|l|l|l|}
\hline 24 & 146 & 441 & 97,699 & & & & & & \\
\hline 25 & 131 & 398 & 98,097 & & & & & & \\
\hline 26 & 119 & 362 & 98,459 & & & & & & \\
\hline 27 & 113 &, 343 & 98,801 & & & & & & \\
\hline 28 &, 089 & 271 & 99,072 & & & & & & \\
\hline 29 &, 082 & 248 & 99,320 & & & & & & \\
\hline 30 & 075 & 226 & 99,546 & & & & & & \\
\hline 31 &, 062 & 189 & 99,735 & & & & & & \\
\hline 32 & 054 & 162 & 99,897 & & & & & & \\
\hline 33 & 034 & 103 & 100,000 & & & & & & \\
\hline
\end{tabular}

Extraction Method: Principal Component Analysis. 
Ek 3. Madde-Toplam Korelasyon İlişkisi

\begin{tabular}{|c|c|c|}
\hline Maddeler & Madde Toplam Korelasyonu & Madde Silinirse Cronbach Alpha Değeri \\
\hline Madde_1 & 392 & 941 \\
\hline Madde_2 & 413 & 941 \\
\hline Madde_3 & 408 & ,941 \\
\hline Madde_4 & 363 & 941 \\
\hline Madde_5 & 344 & 941 \\
\hline Madde_6 & 375 & ,941 \\
\hline Madde_8 & 715 & ,938 \\
\hline Madde_9 & 728 & ,938 \\
\hline Madde_10 & ,739 & ,938 \\
\hline Madde_11 & 751 & ,938 \\
\hline Madde_12 & ,787 & ,937 \\
\hline Madde_13 & 625 & ,939 \\
\hline Madde_14 &, 595 & ,939 \\
\hline Madde_15 & 574 & ,939 \\
\hline Madde_16 & 425 & 941 \\
\hline Madde_17 &, 591 & ,939 \\
\hline Madde_18 & 372 & ,941 \\
\hline Madde_19 & 612 & ,939 \\
\hline Madde_20 &, 52 & 940 \\
\hline Madde_22 & 724 & ,938 \\
\hline Madde_23 & 610 & ,939 \\
\hline Madde_24 & 633 & ,939 \\
\hline Madde_25 & 695 & ,938 \\
\hline Madde_26 & 662 & ,939 \\
\hline Madde_27 & 659 & ,939 \\
\hline Madde_28 & ,538 & ,944 \\
\hline
\end{tabular}


Ayşegül ÖZKAN \& Bülent AKKAYA \& Hasan ÖZKAN

\begin{tabular}{|l|c|c|}
\hline Madde_29 &, 545 &, 944 \\
\hline Madde_30 &, 563 &, 944 \\
\hline Madde_32 &, 690 &, 938 \\
\hline Madde_33 &, 715 &, 938 \\
\hline Madde_34 &, 711 &, 938 \\
\hline Madde_35 &, 727 &, 938 \\
\hline Madde_36 &, 750 & \\
\hline
\end{tabular}




\section{Ek 4. Hizmet Robotu Entegrasyon İsteklilik Ölçeği ve Boyutları}

\begin{tabular}{|c|c|c|}
\hline $\begin{array}{c}\text { Soru } \\
\text { No }\end{array}$ & Boyut & Soru \\
\hline 1 & \multirow{7}{*}{$\begin{array}{l}\text { Performans } \\
\text { Etkinliği }\end{array}$} & Robotlar gibi yapay zekâlı cihazlar, hizmetlerdeki insanlardan daha hatasızdır. \\
\hline 2 & & $\begin{array}{l}\text { Robotlar gibi yapay zekâlı cihazlar tarafından sağlanan bilgiler, hizmetlerde daha az insan hatası ile daha } \\
\text { doğrudur. }\end{array}$ \\
\hline 3 & & Robotlar gibi yapay zekâlı cihazlar, hizmetlerdeki insanlardan daha tutarlı hizmet sunar. \\
\hline 4 & & Robotlar gibi yapay zekâlı cihazlar tarafından sağlanan bilgiler hizmetlerde daha tutarlıdır. \\
\hline 5 & & Robotlar gibi yapay zekâlı cihazlar hizmetlerde insanlardan daha güvenilirdir. \\
\hline 6 & & $\begin{array}{l}\text { Robotlar gibi yapay zekâlı cihazlar tarafından sağlanan hizmet, hizmetlerdeki insan hizmetinden daha } \\
\text { öngörülebilirdir. }\end{array}$ \\
\hline $7^{*}$ & & Yapay zekâlı cihazlar kullanırsam verimsiz kişisel temasları önleyebilirim. \\
\hline 8 & \multirow{6}{*}{$\begin{array}{c}\text { İçsel } \\
\text { Motivasyon }\end{array}$} & Hizmetlerde robotlar gibi yapay zekâlı cihazlarla etkileşimde bulunmaktan keyif alırdım. \\
\hline 9 & & Robotlar gibi yapay zekâlı cihazlarla etkileşim kurmak zevktir. \\
\hline 10 & & Robotlar gibi yapay zekâlı cihazlarla etkileşim kurmak eğlencelidir. \\
\hline 11 & & Hizmet işlemlerinde robotlar gibi yapay zekâlı cihazlarla etkileşimi keyifli buluyorum. \\
\hline 12 & & Robotlar gibi yapay zekâlı cihazlar ile etkileşime girme süreci hoş olurdu. \\
\hline 13 & & Şahsen, robotlar gibi yapay zekâlı cihazların hizmetlerde dost canlısı olduğunu hissediyorum. \\
\hline 14 & \multirow{7}{*}{$\begin{array}{l}\text { Antropomorfizm } \\
\text { (İnsan Biçimcilik) }\end{array}$} & Robotlar gibi yapay zekâlı cihazların kendilerine ait bir zihni olacaktır. \\
\hline 15 & & Robotlar gibi yapay zekâlı cihazlar bilince sahip olacaktır. \\
\hline 16 & & Robotlar gibi yapay zekâlı cihazlar kendi özgür iradelerine sahip olacak. \\
\hline 17 & & Robotlar gibi yapay zekâlı cihazlar duyguları deneyimleyecek. \\
\hline 18 & & Robotlar gibi yapay zekâlı cihazların niyetleri olacaktır. \\
\hline 19 & & Şahsen robotlar gibi yapay zekâlı cihazları şu şekilde hissediyorum - Cansız: Canlı \\
\hline 20 & & Şahsen robotlar gibi yapay zekâlı cihazları şu şekilde hissediyorum - Bilgisayar animasyonlu: Gerçek \\
\hline $21^{*}$ & \multirow{7}{*}{ Sosyal etki } & $\begin{array}{l}\text { İş arkadaşlarımın büyük bir kısmı bunları kullanacaksa, hizmetlerde robotlar gibi yapay zekâlı cihazları } \\
\text { kullanırdım. }\end{array}$ \\
\hline 22 & & $\begin{array}{l}\text { Hizmetlerde robotlar gibi yapay zekâlı cihazların kullanılması, sosyal ağlarım (örneğin arkadaşlar, aile ve iş } \\
\text { arkadaşları) içerisinde bir saygınlı simgesi olarak kabul edilir. }\end{array}$ \\
\hline 23 & & Davranışlarımı etkileyen insanlar, hizmetlerde robotlar gibi yapay zekâlı cihazlar kullanmamı isterlerdi. \\
\hline 24 & & $\begin{array}{l}\text { Hizmetlerde robotlar gibi yapay zekâlı cihazları kullanan sosyal ağlarımdaki insanlar (örneğin, arkadaşlar, aile } \\
\text { ve iş arkadaşları), kullanmayanlardan daha fazla prestije sahiptir. }\end{array}$ \\
\hline 25 & & Fikirlerine değer verdiğim kişiler, hizmetlerde robotlar gibi yapay zekâlı cihazlar kullanmamı tercih ederler. \\
\hline 26 & & $\begin{array}{l}\text { Benim için önemli olan insanlar, beni hizmetlerde robotlar gibi yapay zekâlı cihazları kullanmama teşvik } \\
\text { ediyorlar. }\end{array}$ \\
\hline 27 & & $\begin{array}{l}\text { Hizmetlerde robotlar gibi yapay zekâlı cihazları kullanacak olan sosyal ağlarımdaki insanlar (örneğin, } \\
\text { arkadaşlar, aile ve iş arkadaşları) yüksek bir profile sahiptir. }\end{array}$ \\
\hline 28 & \multirow{4}{*}{$\begin{array}{l}\text { Kolaylaştırıcı } \\
\text { Koşullar }\end{array}$} & Hizmetlerde robotlar gibi yapay zekâlı cihazlarla etkileşimler çok fazla zamanımı alıyor. \\
\hline 29 & & Hizmetlerde robotlar gibi yapay zekâlı cihazlarla çalışmak, anlamak ve kullanmak için çok zordur. \\
\hline 30 & & Hizmetlerde robotlar gibi yapay zekâlı cihazlarla nasıl etkileşim kuracağımı öğrenmek çok uzun sürüyor. \\
\hline $31^{*}$ & & Hizmetlerde robotlar gibi yapay zekâlı cihazlar bana korkutucu geliyor. \\
\hline 32 & \multirow{5}{*}{ Duygular } & Robotlar gibi yapay zekâlı cihazlar kullanırsam, şu şekilde hissedeceğim: Sıkılmış / Rahat \\
\hline 33 & & Robotlar gibi yapay zekâlı cihazlar kullanırsam, şu şekilde hissedeceğim: Mutsuz / Mutlu \\
\hline 34 & & Robotlar gibi yapay zekâlı cihazlar kullanırsam, şu şekilde hissedeceğim: Umutsuz / Umutlu \\
\hline 35 & & Robotlar gibi yapay zekâlı cihazlar kullanırsam, şu şekilde hissedeceğim: Memnuniyetsiz / Memnun \\
\hline 36 & & Robotlar gibi yapay zekâlı cihazlar kullanırsam, şu şekilde hissedeceğim: Keyifsiz / Keyifli \\
\hline
\end{tabular}

*Analiz sonucu ölçekten çıkarılan maddeler. 
Ek 5. Hizmet robotu entegrasyon İsteklilik Ölçeği ve Boyutları (İngilizce)

Performance efficacy

1. Information provided by artificially intelligent devices such as robots is more accurate with less human errors

2. Artificially intelligent devices such as robots are more accurate than human beings

3. Information provided by artificially intelligent devices such as robots are more consistent

4. Artificially intelligent devices such as robots provide more consistent service than human beings

5. Artificially intelligent devices such as robots are more dependable than human beings

6. Service provided by artificially intelligent devices such as robots is more predictable than human service.

7. I am able to avoid inefficient personal contacts if I use artificially intelligent devices such as robots.

\section{Intrinsic motivation}

8. I would have fun interacting with artificially intelligent devices such as robots

9. Interacting with artificially intelligent devices such as robots is fun

10. Interacting with artificially intelligent devices such as robots is entertaining

11. I would find the interaction with artificially intelligent devices such as robots to be enjoyable

12. The actual process of interacting with artificially intelligent devices such as robots would be pleasant

13. I personally feel artificially intelligent devices such as robots are friendly

\section{Anthropomorphism}

14. Artificially intelligent devices such as robots will have consciousness.

15. Artificially intelligent devices such as robotswillhave a mind of theirown.

16. Artificiallyintelligentdevices as robotswillhavetheirownfreewill.

17. Artificially intelligent devices such as robotswillexperienceemotions.

18. Artificially intelligent devices such as robotswillhaveintentions.

19. I personally feel artificially intelligent devices such as robots are Inanimate: Living

20. I personally feel artificially intelligent devices such as robots are Computer animated: Real

\section{Social influence}


such as robots during a service transaction

22. People in my social networks (e.g., friends, family and co-workers) who would utilize artificially intelligent devices such as robots will have more prestige than those who won't

23. People whose opinions that I value would prefer that I utilize artificially intelligent devices such as robots during a service transaction

24. Utilizing artificially intelligent devices such as robots will be status symbol in my social networks (e.g., friends, family and co-workers)

25. People who are important to me would encourage me to utilize artificially intelligent devices such as robots during a service transaction

26. People in my social networks (e.g., friends, family and co-workers) who would utilize artificially intelligent devices such as robots will have a high profile

27. I will utilize artificially intelligent devices such as robots during a service transaction if a significant proportion of my coworkers will use it

\section{Facilitating conditions}

28. It will take me too long to learn how to interact with artificially intelligent devices such as robots

29. Working with artificially intelligent devices such as robots will be so difficult to understand and use.

30. Interactions with artificially intelligent devices such as robots will take too much of my time.

31. Artificially intelligent devices such as robots will be intimidating to me.

\section{Emotions / affects}

32. If I use technological devices/machines such as robots, I will feel Melancholic/Contented

33. If I use technological devices/machines such as robots, I will feel Bored: Relaxed

34. If I use technological devices/machines such as robots, I will feel Despairing: Hopeful

35. If I use technological devices/machines such as robots, I will feel Unsatisfied: Satisfied

36. If I use technological devices/machines such as robots, I will feel Annoyed: Pleased 